\title{
Social Research Institute
}

\section{III}

Unions Increase Job Satisfaction in the United States

Ben Artz

David G. Blanchflower

Alex Bryson

Quantitative Social Science

Working Paper No. 21-13

April 2021 


\section{Disclaimer}

Any opinions expressed here are those of the author(s) and not those of the UCL Social Research Institute. Research published in this series may include views on policy, but the institute itself takes no institutional policy positions.

QSS Workings Papers often represent preliminary work and are circulated to encourage discussion. Citation of such a paper should account for its provisional character. A revised version may be available directly from the author.

Quantitative Social Science

UCL Social Research Institute

University College London

55-59 Gordon Square

London WC1H 0NU 


\title{
Social Research Institute
}

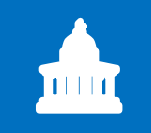

\section{Unions Increase Job Satisfaction in the United States}

\author{
Ben Artz ${ }^{1}$ \\ David G. Blanchflower ${ }^{2}$ \\ Alex Bryson ${ }^{3}$
}

\begin{abstract}
In this paper we revisit the well-known negative association between union coverage and individuals' job satisfaction in the United States, first identified over forty years ago. We find the association has flipped since the Great Recession such that union workers are now more satisfied than their non-union counterparts. We show this to be the case for younger and older workers in the National Longitudinal Surveys of 1979 and 1997. The change is apparent when we use the panel data to account for fixed differences in those who are and are not unionized, suggesting changes in worker sorting into union status are not the reason for the change. The absence of substantial change in the union wage gap, and the stability of results when conditioning on wages, both suggest the change is not associated with changes in unions' wage bargaining. Instead, we find some diminution in unions' ability to lower quit rates - albeit confined to older workers - which is suggestive of a decline in their effectiveness in operating as a 'voice' mechanism for unionized workers. We also present evidence suggestive of unions' ability to minimize covered workers' exposure to underemployment, a phenomenon that has negatively impacted non-union workers.
\end{abstract}

Keywords: job satisfaction; union coverage; union wage gap; quits; underemployment; panel; NLSY

JEL Codes: J28; J50; J51

Acknowledgements: Alex Bryson would like to thank the Norwegian Research Council (grant no. 301280/H20) for financial support. We thank Richard Freeman for helpful comments over the years.

\footnotetext{
${ }^{1}$ Corresponding author. University of Wisconsin, Oshkosh. artzb@uwosh.edu

2 Bruce V. Rauner Professor of Economics, Dartmouth College, Adam Smith Business School, University of Glasgow, NBER and Bloomberg. blanchflower@dartmouth.edu

3 University College London. IZA, Bonn. NIESR, London. a.bryson@ucl.ac.uk
} 


\section{Introduction}

It was in the late 1970s that economists first discovered that unionized workers were less satisfied with their jobs than their non-unionized counterparts. The empirical work conducted by Richard Freeman (1978) and George Borjas (1979) was for the United States. The finding appeared to be at odds with unions' ability to raise wages above those set in the market (Lewis, 1963; 1986) - something which surely would have raised union workers' satisfaction? However, the association persisted even when Freeman incorporated wages as a control variable. Freeman offered an explanation:

"At the 1975 [NBER] meetings, I suggested that the inverse relation might reflect the role of unions as a 'voice' institution, encouraging workers to express discontent during contract negotiations and to make formal grievances rather than to quit, which would keep the dissatisfied from leaving the employer. If this view is correct, the satisfaction relation lends some support to the exit-voice model of the union" (Freeman, 1978: 139140)

Freeman was referring to a model, originally devised by Albert Hirschman (1970) to explain the behavior of consumers when faced with a defective product or deficient service. They could choose to voice their concerns in the hope of rectifying the problem or else leave the provider of the good or service (exit) and seek an improved product or service elsewhere. Applying this model to employment relations, Freeman (1978, 1980) (and subsequently Freeman and Medoff (1984)) suggested that unions, by helping to solve employees' problems at work, made them less likely to quit the workplace than similarly dissatisfied non-union workers so that unions appeared to increase the 'stock' of dissatisfied workers. Freeman (1980) attributed the lower quit rates among unionized workers to the availability of an effective grievance system in the union sector.

However, Blanchflower, Bryson and Green (2021) have shown that this negative correlation between unionization and job satisfaction no longer holds. Indeed, in crosssectional analyses for both the United States and Europe, they find the sign has switched: unionization now appears to be positively correlated with job satisfaction. They go on to use panel data for the UK to find the partial correlation between unionization and job satisfaction remains positive and significant among union switchers. Why this has occurred is not entirely clear.

In this paper we return to the National Longitudinal Survey (NLS) initially used by Freeman (1978) to see whether the relationship between unionization and job satisfaction has indeed switched signs in the United States. We run OLS estimates, as Freeman did, but we also run person fixed effects models to assess whether becoming unionized raises job satisfaction having accounted for fixed unobserved differences between union and nonunion workers which might potentially affect selection into unionization and workers' propensity for job satisfaction. This is a valuable addition to what Freeman (1978) did originally because, as many have argued, those who have a tendency towards dissatisfaction with life, and perhaps also with their jobs, may be more inclined to unionize than those who feel less dissatisfied. Again, following Freeman (1978), we run estimates 
for older and younger workers to see whether effects are robust across cohorts. We run the models for the NLS79, which contains workers born between 1957 and 1964, and those from the NLS97 born between 1980 and 1984.

We find the sign of the union coefficient does indeed switch after the Great Recession. It is positive and statistically significant in both the OLS and person fixed effects panel estimates, and is apparent for the younger and older cohorts, indicating that the emergence of positive union effects on job satisfaction are not driven by those selecting into (out of) unionization. Indeed, the effects are a little larger in the fixed effects models, confirming that those switching into (out of) unionization experienced improvements (deterioration) in their job satisfaction.

The effects are quite sizeable and economically meaningful. Drawing from job satisfaction estimates in the literature that use NLSY data, our union coefficient is approximately equal in size to the positive impact on job satisfaction of having three employer-provided fringe benefits or having a job in the public versus the private sector (Artz, 2010a), nearly the value of taking part in an employer-provided profit-sharing scheme (Heywood and Wei, 2006) and roughly half the effect of getting a promotion (Kosteas, 2011).

We examine three issues that may potentially help explain change in union effects on job satisfaction. The first is a decline in unions' ability to operate as an effective 'voice' for union workers, something that might be apparent from a reduction in their ability to lower quit rates. We find some, albeit limited support, for this proposition among older workers. The second issue is unions' ability to procure a wage premium for covered workers, relative to their non-union counterparts. We extend estimates of the union wage premium we originally ran through to 2002 (Blanchflower and Bryson, 2004) right through to 2019 to see whether union effects on wages had changed over time.

An increase in the union wage premium might conceivably feed through to an increase in the job satisfaction gap between unionized and non-unionized workers, potentially offsetting any (negative) union voice effects on job satisfaction. In fact, the union wage premium has been remarkably constant over time, neither rising nor falling significantly. Yet, given the wage stagnation experienced by many workers, even a constant wage premium in the union sector may generate greater job satisfaction since the Great Recession. We therefore follow Freeman (1978) by plugging wages directly into the job satisfaction equation to net out any potential impact of the union wage premium on unionized workers' relative job satisfaction. The inclusion of wages does not kill the positive association between unionization and job satisfaction, suggesting union wage bargaining is not linked directly to improvements in unionized workers' job satisfaction.

The third issue we explore is the role that underemployment may have played in workers' job satisfaction since the Great Recession. As Bell and Blanchflower (2019) have shown, the Great Recession led to a big rise in underemployment around the world, whereby workers desired far more hours of work than they were able to find in the labor market. This underemployment is the chief reason why there was no upward pressure on wages following the gradual recovery from the Great Recession, despite relatively low 
unemployment rates. Since 2008, Bell and Blanchflower (2021) find that the unemployment rate does not enter wage equations, whereas the underemployment rate does, variously defined, in the US, the UK and in an international sample of countries. This is consistent with John Dunlop's (1944) argument that "wage policy is determined by the employed not the unemployed" (p.69).

To our knowledge, there has been no investigation into the role played by trade unions in protecting unionized workers from underemployment, despite the fact that maintaining one's hours of paid employment is an important aspect of income maintenance, especially in a period of sluggish wage growth. If unions are successful at reducing unionized workers' exposure to underemployment post-recession, this may help explain an increase in their job satisfaction relative to that of non-unionized workers. We confirm that unionized workers are less likely to be underemployed than non-unionized workers, and that the gap is counter-cyclical, rising in periods of recession. However, when we insert hours worked directly into job satisfaction models, although job satisfaction is positively associated with higher working hours, it accounts for none of the union effect on improving job satisfaction since the Great Recession.

The remainder of the paper is set out as follows. Section Two reviews the existing literature, focusing on studies examining links between job satisfaction and unionization in the United States. Section Three presents our data and approach to estimation. Section Four presents our results and Section Five concludes.

\section{Previous Literature}

Although trade unions as institutions vary somewhat across the countries of the world, there is a common acceptance that Freeman and Medoff's (1984) characterization of their 'voice' and 'monopoly' faces captures a large part of what they do at the workplace. These two faces of unionization have potentially countervailing effects on how workers feel about their jobs. On the one hand, unions' ability to monopolize the supply of labor to the employer and thus bargain for wage and non-wage conditions above those set in the absence of unions, should positively impact how covered workers feel about those jobs. This, in turn, should reduce their desire to quit unionized jobs since their outside options set in the market are likely to be inferior. Of course, there is the possibility for dissatisfaction to arise if workers' expectations about bargained outcomes are not met. But the literature is quite clear on this issue: unions continue to procure premia on wages and related conditions such as paid leave, despite some debate about decline in their bargaining power (Blanchflower and Bryson, 2004).

On the other hand, unions' 'voice' face might conceivably generate job dissatisfaction via what Freeman and Medoff (1984) termed 'voice-induced complaining', part of the process by which unions foster support from covered workers strengthening their hand in dealings with the employer, or though the increased flow of information that comes to unionized workers as a result of the two-way communication between management and employees which is a pre-requisite for unions in representing their members. This, together with the increased likelihood of dissatisfied workers remaining in the presence of union voice - as predicted under the exit, voice, loyalty model discussed above - results in cross-sectional 
estimates of the partial correlation between unionization and job dissatisfaction originally identified in the work of Freeman (1978) and Borjas (1979). ${ }^{4}$

In his original paper Freeman (1978) partly motivated the importance of job satisfaction as a variable, economists should be interested in, by showing that it was a strong predictor of labor mobility. Using panel data on older men in the NLS Older Men and NLS Younger Men samples and the Michigan Panel Survey of Income Dynamics (PSID) Freeman showed job dissatisfaction predicted higher quit rates in the late 1960s and early 1970s (1978: 137). However, unionization was associated with both lower job satisfaction and lower quit rates in the Michigan PSID and NLS Older Male samples which, he argued, was consistent with unions providing effective voice for workers, thus reducing their quit probabilities for a given level of job dissatisfaction. He revisits the issue in his Freeman (1980) paper using the same data sets plus the Current Population Survey (CPS), confirming reduced separation rates among unionized workers, particularly among the least satisfied workers. The reduction in quits among unionized workers is apparent having conditioned on wages (p. 666) which are intended to net out potential monopoly face benefits of unionization, thus isolating voice effects. ${ }^{5}$

Borjas (1979) comes to similar conclusions analyzing data from the National Longitudinal Survey of Mature Men aged 50-64. His estimates of union negative associations with job satisfaction are robust to his efforts to account for potential simultaneity using an instrumental variables approach. But he goes a stage further in testing the voice hypothesis for union dissatisfaction effects by showing the effects are strongest among workers with high tenure. ${ }^{6}$ The effects hold when conditioning on wages too. However, he adds to Freeman's analysis of quits by showing the union effect in reducing quits is largely confined to low tenured workers, a finding he attributes to the flatter wage profile faced by older workers arising from the seniority wage system promoted by unions.

Blanchflower and Oswald (1999) estimated job satisfaction equations using data from the US General Social Survey from 1972-1996 as well as the 1989 International Social Survey Programme across a sample of ten countries including Germany, UK, USA, Austria, Hungary, Netherlands, Italy, Ireland, Norway and Israel. In both cases they found that a union variable was significantly negative. Artz (2010b) also found a negative union coefficient in a job satisfaction equation based on panel data for the period 1979-2004 from the National Longitudinal Survey of Youth. ${ }^{7}$

\footnotetext{
${ }^{4}$ Borjas (1979: 21) expressly refers to the "politicization of the unionized labor force" as a contributory factor. In a study for the UK, Bender and Sloane (1998) confirm that unions negatively impact the climate of employment relations at the workplace and that, when one accounts for this, the association between unionization and job dissatisfaction is no longer significant. They conclude that "union workers' relative dissatisfaction....stems from poor industrial relations or from unions forming where satisfaction would be low anyway" (p. 222).

${ }^{5}$ A parallel literature using establishment-level data for Britain confirms a partial correlation between the presence of union voice and lower quit rates (Bryson et al., 2013). The effect did not vary significantly over the period 1990-2004 despite declining within-establishment union density, something which may have impaired the effectiveness of union voice.

${ }^{6}$ Borjas' contention is that low tenure workers provide information to the firm about the problems workers face via exit whereas high tenure workers provide that information through expressed dissatisfaction (p. 30). ${ }^{7}$ See also Artz (2012).
} 
As noted above, Blanchflower, Bryson and Green (2021) have established that the partial correlation between unionization and job dissatisfaction no longer holds in the United States and in Europe. Their estimates for the United States, based on data from the General Social Survey for the period 1972-2018, confirm Freeman (1978) and Borjas' (1979) and Blanchflower and Oswald's (1999) finding of a negative correlation between unionization and job satisfaction in the early years. However, the correlation turned positive and statistically non-significant between 1998 and 2008 and became positive and statistically significant after the Great Recession. They confirm this positive, significant correlation for the period after the Great Recession in data from the Gallup Daily Tracker. Investigating why the change may have occurred they present evidence from analyses of the General Social Survey indicating that unionized workers were more likely than their non-union counterparts to expect job loss in the period prior to the Great Recession, but that this was no longer the case after 2008. At the same time, union workers continued to benefit from a wage premium. They conclude: "This likely helps to explain the positive coefficient in the job satisfaction equations: union workers are less fearful of job loss than previously, yet they continue to receive the substantial wage premium they have always received" (p. 13).

Blanchflower, Bryson and Green (2021) also consider the possibility that changes in the composition of union and non-union workers over time may have contributed to changes in the correlation between job satisfaction and union status. They do so by examining the partial correlation between job satisfaction and union status in the Gallup Daily Tracker data for the period 2009-2013 for members of different birth cohorts. They find early birth cohorts who would have made up most of the sample in Freeman and Borjas' studies in the 1970s continued to exhibit a negative union partial correlation with job satisfaction, whereas subsequent birth cohorts (born after 1959) exhibited a positive partial correlation. ${ }^{8}$

There is, as yet, no obvious explanation for the role of birth cohorts in the change in the partial correlation between job satisfaction and unionization, although the persistent negative correlation between job satisfaction and unionization among earlier birth cohorts may be related to Artz's (2010b) finding based on panel data for the period 1979-2004 from the National Longitudinal Survey of Youth which showed the negative association between unionization and job satisfaction increased with union experience. In any event, the finding points to the potential importance of accounting for compositional change in those becoming unionized.

One way to do this is to undertake panel estimation which focuses on changes in union status within individuals over time, thus accounting for fixed unobserved differences across union and non-union workers over time. There are a number of such estimates for the United Kingdom, and these tend to show the negative partial correlation between job satisfaction and union status is ameliorated and, in some cases, even switches sign with the inclusion of person fixed effects.

\footnotetext{
${ }^{8}$ They subsequently confirmed the persistence in the negative partial correlation between job satisfaction and unionization in a UK birth cohort born in 1958 (Blanchflower and Bryson, 2020).
} 
The most recent example is the only panel analysis presented in Blanchflower, Bryson and Green (2021). These estimates, based on data from the British Household Panel Survey and its successor Understanding Society for the period 1996-2018, show the union partial correlation with job satisfaction is negative and statistically significant in OLS estimates but becomes positive and statistically significant when introducing person fixed effects which net out fixed unobserved differences between union and non-union workers. ${ }^{9}$ However, the authors do not present estimates for early and later periods. There is no recent panel evidence on the association between unionization and job satisfaction for the United States, so it is unclear what their incorporation might imply for the switch in the union partial correlation with job satisfaction apparent in OLS estimates. We address this issue below.

If the switch in the partial correlation between job satisfaction and unionization is linked to a diminution in union effectiveness as a 'voice' for unionized workers, a corollary might be a reduction in unions' capacity to lower quit rates. We investigate this issue below.

Finally, when considering how union effects on job satisfaction may have changed since the Great Recession it is important to recall the importance of changes in labor market trends since 2008. The discussion above noted the potential role played by unions in insuring against job loss, but another potential role unions might play relates to their ability to guarantee income security through the avoidance of underemployment. The issue of underemployment has come to the fore in the United States and elsewhere since the Great Recession (Bell and Blanchflower, 2019). In a period characterized by wage stagnation and recession-induced unemployment, it might not be surprising to find unions bargaining to maintain covered workers' hours to ensure income security. However, nobody has investigated this issue to date.

\section{Data and Estimation}

In accordance with the previous literature reviewed in Sections One and Two we estimate job satisfaction equations using Ordinary Least Squares (OLS) estimation supplemented with models incorporating person fixed effects. The fixed effects estimator holds constant all time-invariant unobserved individual characteristics that may affect selection into union status and job satisfaction, thus measuring changes in job satisfaction as an individual's union status changes. This approach requires longitudinal panel data tracking workers and their job satisfaction over time.

In the United States, the National Longitudinal Survey of Youth (NLSY) is the most widely used and respected panel containing both job satisfaction and union status measures, and it is one of two data sets Freeman (1978) used in his examination of unionization and job satisfaction. We analyze two separate cohorts from the NLSY. The first cohort (NLS79), born between 1957 and 1964, were first interviewed as teenagers in 1979, and were most recently reinterviewed in 2018. The second cohort (NLS97), born between 1980 and 1984, were first interviewed in 1997 and were most recently surveyed in 2017.

\footnotetext{
${ }^{9}$ For earlier similar results for the UK see Bryson and White (2016a, 2016b).
} 
Both surveys initially interviewed individuals annually but shifted to a biennial survey (from 1994 in the case of the NLS79 and from 2011 in the case of the NLS97). In addition to union status and job satisfaction, both cohorts contain information on demographic and job characteristics which we include as covariates in our estimations. These include gender, race, age, region of residence, education level, marital status, the presence of children, and the job's industry and occupation. Summary statistics separately for the 1979 and 1997 NLSY cohorts are presented in Table 1.

The way union status is identified in the NLS79 differs over time. The survey records union membership status in 1979 and in the period 1988 to 2018. Between 1979 and 1993 workers were asked whether their wages were set by a collective bargaining agreement. And between 1994 and 2018 the survey asked whether workers were covered by union contracts. The NLS97 merely asks whether respondents are covered by a contract negotiated by a union. Since no single measure exists across all waves in the NLS79, and since in the United States there is little difference between union membership and union coverage by a collectively bargained contract, we combine all three measures in NLS79 to form a single union status measure similar to that in the NLS97. ${ }^{10}$

We confine our analyses to overall job satisfaction because satisfaction with facets of the job is only available in a sub-set of waves. The two cohorts use nearly identical wording to record workers' job satisfaction. NLS79 respondents are asked "How do you feel about the job you have now?" whilst NLS97 respondents are asked "Which of the following best describes how you feel about your job?". NLS97 offers five responses ranging from "dislike it very much" to "like it very much", including a "neutral" response in the middle. The NLS79 omits the neutral response and consequently offers only four options. ${ }^{11}$

The self-employed and those working in the military and private households are removed from the estimation sample to increase the comparability of employees entering the union and non-union samples. We also restrict the estimation sample to those in the private sector. Although unions loom large in government settings, their role and bargaining power are somewhat different to those in private sector settings. Moreover, in many instances public and private sector jobs consist of distinct tasks and employment relationships, making job satisfaction comparisons difficult. Finally, to address potential concerns that respondent non-response or attrition in some variables may bias our results we estimate job satisfaction using a sample that omits missing observations and another that retains those with missing observations through imputation. The final job satisfaction estimation samples are approximately 161,000 and 68,000 in the NLS79 and NLS97 respectively.

We also examine the partial correlation between union status and the propensity to quit using NLS79 and NLS97. We run linear estimation models on the $(0,1)$ voluntary quit outcome where 1 denotes all worker-initiated (voluntary) job separations except for family

\footnotetext{
${ }^{10}$ Throughout the union status measures also encompass membership of "employee associations". We cannot disentangle the two. We remove the 1994 wave of the NLS79 from the estimation sample due to inaccurate or incomplete union data in the wave arising due to recording errors in the union coverage variables.

${ }^{11}$ NLS79 records all workers' job satisfaction. However, NLS97 limits the question to those workers who have been at their employer for more than 12 weeks, thus reducing the estimation sample in the NLS97.
} 
or pregnancy reasons. These separations specifically identify workers quitting to look for another job, take another job, or for other reasons: they exclude employer-initiated job loss.

We estimate the union wage gap in the same fashion as Blanchflower and Bryson (2004) using the Monthly Outgoing Rotation Group (MORG) nested within the Current Population Survey (CPS). These data are publicly available for download at the NBER see https://www.nber.org/research/data/current-population-survey-cps-data-nber

Finally, we examine union effects on both job satisfaction and the Cantril Ladder, a second subjective wellbeing metric, using the Gallup Daily Tracker which tracks around 1,000 people per day in the United States. Although the data are only available from 2009, so do not permit us to establish what changed pre- and post-2008 resulting in the union partial correlation with job satisfaction turning positive, the sample sizes are large and the data contain measures of underemployment - part-time workers expressing a desire for more paid hours - thus allowing us to test the proposition that some of the higher job satisfaction among union workers relative to non-union workers is their increased ability to avoid underemployment.

\section{Results}

Figure 1 presents mean job satisfaction for private sector union and non-union workers in the NLS79 over the period 1979-2018. Among these workers, born between 1957 and 1964 , mean job satisfaction is lower for the union than the non-union workers, apart from in the period since 2008 .

To assess whether the switch in the union association with job satisfaction is statistically significant and robust to the introduction of controls, we present regression-adjusted estimates in Table 2. We code the dependent variables such that a positive coefficient means higher job satisfaction. The first three columns of the table present pooled OLS cross-sectional estimates. Column 1 reports union status interacted with time-period, with year dummies as the only additional controls. Missing observations are included following imputation. Column 2 is run on the same sample but incorporates the demographic traits reported in the table, together with additional controls for regional location, occupation and industry. Column 3 is identical to column 2 but drops the cases with missing information.

The models in columns 4-6 exploit the panel nature of the data by incorporating person fixed effects to identify changes in job satisfaction within person over time and their links to changes in union status. For this reason, some of the fixed observed traits of individuals such as race fall out of the models, but otherwise they follow the model specification in columns 1-3.

The main effect of union status in columns 1-3, which captures its partial correlation with job satisfaction in the period prior to 1989 , is negative and is statistically significant in Models 1 and 3. But what is particularly striking is the positive and precisely estimated change in the union interaction with job satisfaction from 2008: the interaction term union*2008-2018 is positive and highly statistically significant in all three models indicating a significant change in the union effect on job satisfaction relative to its impact 
in the base period prior to 1989. Combining the main and interaction effects it is apparent that unionized workers are significantly more satisfied with their jobs than their nonunionized counterparts in the post-Great Recession period. ${ }^{12}$

Appendix Table 1 splits the estimates into pre- and post-Great Recession sub-samples to aid interpretation of the interaction terms: union status is associated with an increase of roughly 0.05 points on the job satisfaction scale post-Great Recession. The effect is roughly equivalent in size to the positive impact on job satisfaction of having three employer-provided fringe benefits or having a job in the public versus the private sector (Artz, 2010a), nearly the value of taking part in an employer-provided profit-sharing scheme (Heywood and Wei, 2006) and roughly half the effect of getting a promotion (Kosteas, 2011).

One potential reason for this switch in the union partial correlation with job satisfaction could be a change in the composition of union and non-union workers over time. If those workers sorting into (out of) unionization have a greater (lower) propensity for job satisfaction over time, this might explain the increasing propensity for unionized workers to be more satisfied with their jobs than non-unionized workers. We can discount this possibility based on the estimates in columns 4-6 in Table 2 because they confirm the positive and highly statistically significant interaction between union status and the period from 2008 onwards is robust to the inclusion of person fixed effects. These estimates confirm that the union partial correlation with job satisfaction switched positive in the period from 2008 among union switchers. That is to say, the change is apparent within workers over time, so cannot be driven by time-variance in the fixed unobserved traits of union and non-union workers.

Figure 2 and Table 3 repeat the exercise, but this time for the younger NLS97 cohort whose job satisfaction is recorded over the period 1997-2017. The figure indicates that the raw difference in mean job satisfaction favors non-union workers until the onset of the Great Recession where, for a few years, the union differential appears negligible. Then from 2011/12 job satisfaction appears higher among unionized workers.

Turning to the regression analyses in Table 3, although the interaction of union status with the post-Great Recession period is positive it is not statistically significant at conventional levels in the OLS estimates presented in columns 1-3. However, the estimates become far more precise with the introduction of person fixed effects such that the interaction is positive and statistically significant in columns 4-6.

The recent positive partial correlation between unionization and job satisfaction in both NLS cohorts, and its robustness to fixed unobserved differences across individuals, raises two related questions, namely whether the change is associated with a change in job quit behavior between union and non-union workers, and what might lie behind the change?

\footnotetext{
${ }^{12}$ In column 3 the net effect is $-.021+.067=+.046$.
} 
We begin by considering whether the positive partial correlation between unionization and job satisfaction since the Great Recession indicates a decline in union effectiveness as a voice mechanism for workers. Freeman (1978: pp. 139-140) had suggested that union voice effects may explain the otherwise paradoxical finding that unions lower quit rates despite raising job dissatisfaction, something which is otherwise known to raise quit rates. Therefore, a corollary of unionization being associated with higher job satisfaction since the Great Recession might be a diminution in unions' ability to lower quit rates by providing effective voice for workers.

Figures 3 and 4 plot quit rates for union and non-union workers separately for the NLS79 and NLS97 respectively. Figure 3 is suggestive of a closure in quit rates between union and non-union workers, but only at the height of the Great Recession in 2008 and again in 2018. In the NLS97 non-union quit rates have been persistently higher than those for union workers since the early 2000s, though they do close between 2015-2017 (Figure 4).

We test more formally for a change in relative quit rates among union and non-union workers by running regressions similar to those in Tables 1 and 2 for job satisfaction. Table 4 presents linear estimation models for the $(0,1)$ probability of quitting the job over the period 1979-2018 among those born between 1957 and 1964 in the NLS79. The negative union effect on quits is apparent for the base period before 1989 in row 1 of the table and is represented by the union coefficient. However, the union interaction with the period post the on-set of the Great Recession is positive and statistically significant in all model specifications - both OLS and person fixed effects models - indicating that the union association with lower quit rates has dissipated. If we take column 6 , for example, which conditions on worker fixed effects, the interaction effect exactly offsets the union effect in the base period prior to 1989, implying those who switched union status over the period were no more nor less likely to quit their jobs than their non-union counterparts.

The union effect on quits is quite different for the younger people surveyed in the NLS97 born between 1980 and 1984. Union effects are largely absent for quits among these younger workers over the period 1997-2017, and do not vary significantly over time, as indicated by the weak or zero significance of the union interaction term with the postrecession period (Table 5).

Taken together, the evidence from Tables 4 and 5 is that, if unions were associated with lower quit rates, the association may have been apparent for older workers and was confined to the period prior to the Great Recession. Together with our finding that the partial correlation between job satisfaction and unionization turned positive post-Great Recession, there is some indication that the efficiency with which unions provide workers with voice may have declined somewhat recently.

Next, we turn to the possibility that changes in unions' effectiveness in procuring a union wage premium may help explain the increase in job satisfaction among union relative to non-union workers. The final column of Table 6 presents estimates of the regressionadjusted union wage gap in the CPS MORG using the methodology previously deployed by Blanchflower and Bryson (2004). The union wage gap has fluctuated between 12-15\% 
between 2000 and 2019, but shows no discernible pattern, suggesting change in the union wage premium is unlikely to explain rising job satisfaction among union relative to nonunion workers. ${ }^{13}$

However, it may be that job satisfaction has simply become more sensitive to a given wage level, such that the job satisfaction returns to a constant union wage premium may have risen over time. To establish whether this is a possibility we conditioned directly on earnings in the NLSY job satisfaction equation. The results, presented in Appendix Table 2, are robust to this sensitivity check in both the NLS79 and NLS97.

Finally, we turn to the issue of underemployment and the possibility that positive union correlations with job satisfaction since the Great Recession may reflect unions' ability to shore up unionized workers' income by ensuring they continue to work sufficient hours. It is apparent from columns 1 and 2 of Table 6 and Appendix Chart 1 that underemployment rates rose after the Great Recession, only returning to their pre-recession levels in 2016/17, but it should be noted they have still not returned to the lower rates observed at the start of the millennium. It is also apparent from columns 1 and 2 of Table 6 that underemployment rates were much higher among non-union workers than among union workers throughout the first two decades of the century. They were one-third higher among the non-union workers at the beginning and end of the period, but the underemployment rate was actually double for the non-employed in 2016.

Workers in search of additional paid hours of work may have sought second jobs or supplemented their income with self-employment, but Bureau of Labor Statistics figures indicate this did not happen. This suggests that workers were 'stuck' off their labor supply curves due to depressed labor demand. It is perhaps no surprise to discover, therefore, that the underemployed - whether unionized or not - were less happy with their jobs than other workers, both on the job satisfaction and Cantril Ladder metrics (Table 7). It is also notable that among the under-employed, non-union workers were less happy than union workers.

To establish whether underemployment may play a role in the job satisfaction of union workers relative to non-union workers post-Great Recession we ran estimates for job satisfaction and life satisfaction using the Gallup Daily Tracker. These estimates, which are the first in the literature to consider the links between unionization, underemployment and employee wellbeing, are presented in Table 8.

Panel A shows the importance of underemployment for job and life satisfaction. Whereas those in part-time employment who do not want additional hours are more satisfied than full-time employees (the reference category), those part-timers who want additional hours are significantly less satisfied with their jobs and with life than full-time employees. Panel A also shows union workers are more satisfied with their jobs, and with life, than their nonunion counterparts, confirming our earlier work (Blanchflower, Bryson and Green 2021).

\footnotetext{
${ }^{13}$ The union hourly wage differential estimates here extend the results in Table 5 for the period 1973-2002 in Blanchflower and Bryson (2004) using the same data and excluding workers with allocated earnings. The results for 2000 and 2001 are identical but there is a slight difference in the estimates for 2002 of $18.6 \%$ in the earlier paper and $13.7 \%$ here. The prior 2002 estimate of $18.6 \%$ was in error.
} 
Panel B extends the analysis by interacting union status with underemployment. The interaction coefficients in both the job and life satisfaction equations are positive and statistically significant, partly offsetting the large negative and statistically significant effects of underemployment these workers would have experienced if non-unionized. A significant, positive union effect persists even when introducing the interaction between unionization and underemployment, so unions' ability to combat the worst effects of underemployment are not the sole reason for the positive union association with worker wellbeing post-Great Recession. It would therefore appear that the switch in the union coefficient on job satisfaction from negative to positive is due, in part, both to the lower rates of underemployment in the union sector compared to the non-union sector, as well as unions' ability to ameliorate the negative effects of underemployment on workers' satisfaction. ${ }^{14}$

\section{Conclusions}

In this paper we revisited the well-known negative association between unionization and individuals' job satisfaction in the United States, first identified over forty years ago. We find the association has flipped since the Great Recession such that union workers are now more satisfied than their non-union counterparts. We show this to be the case for younger and older workers in the National Longitudinal Surveys of Youth of 1979 and 1997. The change is apparent when we use the panel data to account for fixed differences in those who are and are not unionized, suggesting changes in worker sorting into union status are not the reason for the change.

The absence of substantial change in the union wage gap over time suggests the change is not associated with changes in unions' wage bargaining. Incorporating wages directly into satisfaction equations does not affect the union coefficient, suggesting union-induced changes to job satisfaction do not arise due to increased sensitivity to a given union wage premium. Instead, we find some diminution in unions' ability to lower quit rates - albeit confined to older workers - which is suggestive of a decline in their effectiveness in operating as a 'voice' mechanism for unionized workers. We also present evidence suggestive of unions' ability to minimize covered workers' exposure to underemployment, a phenomenon that has been particularly detrimental to the wellbeing of non-union workers.

\footnotetext{
${ }^{14}$ This last point is somewhat reminiscent of recent work suggesting unions are able to ameliorate the adverse wellbeing effects of other aspects of labor market experience, such as workers' exposure to anxiety-inducing innovation at the workplace (Bryson et al., 2013).
} 


\section{References}

Artz, B. (2012) 'Does the impact of union experience on job satisfaction differ by gender?' Industrial and Labor Relations Review, 65(2), pp. 225-243.

Artz, B. (2010a), 'Fringe benefits and job satisfaction,' International Journal of Manpower, 31(6), pp. 626-44.

Artz, B. (2010b) 'The impact of union experience on job satisfaction,' Industrial Relations, 49(3), pp. 387-405.

Bell, D.N.F and Blanchflower, D. G. (2011) 'Youth unemployment in Europe and the United States,' Nordic Economic Policy Review, 1, pp. 11-38.

Bell, D.N.F and Blanchflower, D.G. (2019) 'Underemployment in the United States and Europe', Industrial and Labor Relations Review, 74 (1), pp. 56-94

Bender, K.A. and Sloane, P.J. (1998), 'Job satisfaction, trade unions, and exit-voice revisited,' Industrial and Labor Relations Review, 51(2), pp. 222-240. https://doi.org/10.1177/001979399805100204

Bessa, I., Charlwood, A. and Valizade, D. (2020), 'Do unions cause job dissatisfaction? Evidence from a quasi-experiment in the United Kingdom?' British Journal of Industrial Relations, 1-29, first online May $18^{\text {th }} 2020$.

Blanchflower, D.G. (1984), 'Union relative wage effects; a cross-section analysis using establishment data,' British Journal of Industrial Relations, 22(3), pp. 311-332.

Blanchflower, D. G., A. Bryson, and C. Green (2021), 'Now unions increase job satisfaction and wellbeing,' previously NBER Working Paper 27720

Blanchflower, D. G. and Bryson, A. (2020) "Job satisfaction over the life course", NBER Working Paper 28206.

Blanchflower, D. G. and Bryson, A. (2004), 'What effects do unions have on wages now and would Freeman and Medoff be surprised?,' Journal of Labor Research, 25(3), pp. 383414 and in What Do Unions Do? The Evidence Twenty Years Later (2006) edited by J.T. Bennett and BE. Kaufman.

Borjas, G. (1979), 'Job satisfaction, wages, and unions,' Journal of Human Resources, 14(1), pp. 21-40.

Bryson, A. (2005) 'Union effects on employee relations in Britain', Human Relations, 58, 9: 1111-1139

Bryson, A. Cappellari, L. and Lucifora, C. (2004), 'Does union membership really reduce job satisfaction?', British Journal of Industrial Relations, 42(3): pp. 439-459. 
Bryson, A., Cappellari, L. and Lucifora, C. (2010), 'Why so unhappy? The effects of unionization on job satisfaction', Oxford Bulletin of Economics and Statistics, 72(3), pp. 357-380.

Bryson, A., Dale-Olsen, H. and Barth, E. (2013), 'The effects of organizational change on worker wellbeing and the moderating role of trade Unions', Industrial and Labor Relations Review, 66(4), pp.989-1011

Bryson, A. and White, M. (2016a), 'Unions and the economic basis of attitudes,' Industrial Relations Journal, 47, 4 pp. 360-378.

Bryson, A. and White, M. (2016b), 'Not so dissatisfied after all? The impact of union coverage on job satisfaction,' Oxford Economic Papers, 68(4), pp.898-919.

Bryson, A., Willman, P., Gomez, R. And Kretschmer, T. (2013) 'The Comparative Advantage of Non-Union Voice in Britain, 1980-2004,' Industrial Relations: A Journal of Economy and Society, 52, S1: 194-220

Duncan, G. J. and Stafford, F. P. (1980), 'Do union members receive compensating wage differentials?' The American Economic Review, 70(3), pp. 355-371.

Dunlop, J. (1944), Wage Determination Under Trade Unions, New York, Augustus Kelley.

Freeman, R.B. (1978), 'Job satisfaction as an economic variable,' American Economic Review, 68(2), pp.135-41.

Freeman, R.B. (1980), 'The exit-voice tradeoff in the labor market: unionism, job tenure, quits, and separations,' The Quarterly Journal of Economics, 94(4), pp. 643-673. https://doi.org/10.2307/1885662

Freeman, R. and J. Medoff, (1984), What Do Unions Do? Basic Books.

Gordon, M.E. and Denisi, A.S. (1995), 'A re-examination of the relationship between union membership and job satisfaction,' Industrial and Labor Relations Review, 48(2), pp. 222236.

Green, C. and Heywood, J. (2014), 'Dissatisfied union workers: sorting revisited,' British Journal of Industrial Relations, 53(3), pp. 580-600.

Heywood, J.S., and Wei, X. (2006), 'Performance pay and job satisfaction,' Journal of Industrial Relations, 48(4), pp. 523-40.

Heywood, J. S., Siebert, W.S., and Wei, X. (2002), 'Worker sorting and job satisfaction: the case of union and government Jobs,' Industrial and Labor Relations Review, 55(4), pp. 595-609. 
Hirschman, A. O. (1970) Exit, Voice and Loyalty: Responses to Decline in Firms, Organizations and States, Harvard University Press

Kosteas, V. D. (2011), 'Job satisfaction and promotions,' Industrial Relations, 50(1), pp. 174-94.

Leigh, D. (1981), 'Do union members receive compensating wage differentials? Note,' American Economic Review, 71(5), pp. 1049-1055.

Lewis, H. G. (1963), Unionism and Relative Wages in the United States, Chicago, Ill.: University of Chicago Press.

Lewis, H. G. (1986), Union Relative Wage Effects: A Survey, Chicago, Ill.: University of Chicago Press.

Millward, N., Bryson, A. and Forth, J. (2000), All Change at Work? Routledge, London.

Powdthavee, N. (2011), 'Anticipation, free-rider problems, and adaptation to trade unions: re-examining the curious case of dissatisfied union members,' Industrial and Labor Relations Review, 64(5), pp. 1000-1019. 
Table 1: Summary statistics - mean (standard deviation in parentheses)

\begin{tabular}{|c|c|c|}
\hline NLSY variable descriptions & 1979 cohort & 1997 cohort \\
\hline $\begin{array}{l}\text { Job satisfaction: "How do you feel about the job you } \\
\text { have now?" from } 1 \text { "dislike it very much" to } 4 \text { or } 5 \text { "like } \\
\text { it very much"\$ }\end{array}$ & $\begin{array}{c}3.258 \\
(0.744)\end{array}$ & $\begin{array}{c}3.898 \\
(1.040)\end{array}$ \\
\hline $\begin{array}{l}\text { Quit: = } 1 \text { if respondent voluntary quits their job, } \\
\text { excluding for pregnancy or family reasons; } 0 \text { otherwise }\end{array}$ & $\begin{array}{c}0.061 \\
(0.240)\end{array}$ & $\begin{array}{c}0.091 \\
(0.287)\end{array}$ \\
\hline $\begin{array}{l}\text { Union status: }=1 \text { if respondent is covered by a union } \\
\text { contract and } 0 \text { otherwise. } \%\end{array}$ & $\begin{array}{c}0.138 \\
(0.345)\end{array}$ & $\begin{array}{c}0.083 \\
(0.276)\end{array}$ \\
\hline Male: $=1$ if respondent is male and 0 otherwise. & $\begin{array}{c}0.535 \\
(0.499) \\
\end{array}$ & $\begin{array}{c}0.511 \\
(0.500)\end{array}$ \\
\hline Age: respondent's age in years. & $\begin{array}{c}31.672 \\
(10.954)\end{array}$ & $\begin{array}{l}24.734 \\
(6.194)\end{array}$ \\
\hline Age squared / 100 & $\begin{array}{l}11.231 \\
(7.973)\end{array}$ & $\begin{array}{c}6.387 \\
(2.682)\end{array}$ \\
\hline Black: $=1$ if respondent is Black and 0 otherwise. ${ }^{\&}$ & $\begin{array}{c}0.253 \\
(0.435)\end{array}$ & $\begin{array}{c}0.233 \\
(0.423)\end{array}$ \\
\hline $\begin{array}{l}\text { Hispanic: }=1 \text { if respondent is Hispanic and } 0 \text { otherwise. } \\
\text { H }\end{array}$ & $\begin{array}{c}0.170 \\
(0.376)\end{array}$ & $\begin{array}{c}0.215 \\
(0.411)\end{array}$ \\
\hline $\begin{array}{l}\text { High school education: }=1 \text { if respondent has fewer than } \\
16 \text { years of education and } 0 \text { otherwise. }\end{array}$ & $\begin{array}{c}0.687 \\
(0.464)\end{array}$ & $\begin{array}{c}0.563 \\
(0.496)\end{array}$ \\
\hline $\begin{array}{l}\text { College education: }=1 \text { if respondent has greater than } 15 \\
\text { years of education and } 0 \text { otherwise. }\end{array}$ & $\begin{array}{c}0.148 \\
(0.355)\end{array}$ & $\begin{array}{c}0.197 \\
(0.398)\end{array}$ \\
\hline $\begin{array}{l}\text { Marital status: }=1 \text { if respondent is married and } 0 \\
\text { otherwise. }\end{array}$ & $\begin{array}{c}0.440 \\
(0.496)\end{array}$ & $\begin{array}{c}0.228 \\
(0.419)\end{array}$ \\
\hline $\begin{array}{l}\text { Children: the number of children in respondent's } \\
\text { household (range }=0-10 \text { ) }\end{array}$ & $\begin{array}{c}0.769 \\
(0.496)\end{array}$ & $\begin{array}{c}0.958 \\
(1.197)\end{array}$ \\
\hline Occupations & 21 categories & 21 categories \\
\hline Industries & 15 categories & 15 categories \\
\hline Regions of residence & 4 categories & 4 categories \\
\hline Years / panel waves @ & 27 years & 18 years \\
\hline Observations $^{\#}$ & 161,078 & 67,750 \\
\hline \multicolumn{3}{|c|}{$\begin{array}{l}\text { Notes: } \\
\text { \$ Job satisfaction: } 4 \text { categories in the } 1979 \text { cohort and } 5 \text { categories in the } 1997 \text { cohort. } \\
\% \text { We omit the } 1994 \text { wave from the } 1979 \text { NLSY panel due to recording errors when } \\
\text { collecting information regarding union status. Union status combines union membership, } \\
\text { collectively bargained wages, and coverage under a union bargained contract. } \\
\& \text { The NLSY over-samples racial minorities. } \\
\text { @ } 1979 \text { cohort: annual waves from } 1979 \text { to } 1993 \text { and biennial thereafter until } 2018 \text {; } \\
1997 \text { cohort: annual waves from } 1997-2011 \text { and biennial thereafter until } 2017 . \\
\text { \# We omit all private household employees, self-employed workers, military and public } \\
\text { sector employees from the working sample. }\end{array}$} \\
\hline
\end{tabular}


Table 2: Job Satisfaction, NLS79: 1979 - 2018

\begin{tabular}{|c|c|c|c|c|c|c|}
\hline & OLS poole & $d$ cross-sect & ions & OLS fixed & effects & \\
\hline & (1) & (2) & (3) & (4) & (5) & (6) \\
\hline Union & $-0.028 * * *$ & -0.010 & $-0.021 * *$ & $0.021 * *$ & $0.017 *$ & 0.012 \\
\hline & $(2.59)$ & $(1.00)$ & $(1.97)$ & $(2.21)$ & $(1.76)$ & $(1.23)$ \\
\hline $1989-1996$ & $0.271 * * *$ & $0.139 * * *$ & $0.095 * * *$ & $0.241 * * *$ & $0.151 * * *$ & $0.135 * * *$ \\
\hline & $(19.16)$ & $(4.62)$ & $(3.01)$ & $(17.09)$ & $(9.60)$ & $(8.06)$ \\
\hline $1998-2006$ & $0.317 * * *$ & $0.152 * * *$ & $0.104 * *$ & $0.283 * * *$ & $0.178 * * *$ & $0.157 * * *$ \\
\hline & $(21.16)$ & $(3.41)$ & $(2.26)$ & $(18.90)$ & $(10.57)$ & $(8.71)$ \\
\hline $2008-2018$ & $0.268 * * *$ & 0.062 & 0.034 & $0.217 * * *$ & $0.113 * * *$ & $0.095 * * *$ \\
\hline & $(16.66)$ & $(0.86)$ & $(0.47)$ & $(13.65)$ & $(6.56)$ & $(5.236)$ \\
\hline Union x 1989 - 1996 & -0.019 & 0.005 & 0.015 & $-2.29 \times 10^{-4}$ & 0.005 & 0.010 \\
\hline & $(1.22)$ & $(0.33)$ & $(0.98)$ & $(0.02)$ & $(0.38)$ & $(0.68)$ \\
\hline Union x 1998 - 2006 & -0.006 & 0.008 & 0.014 & 0.004 & 0.010 & 0.012 \\
\hline & $(0.332)$ & $(0.45)$ & $(0.72)$ & $(0.24)$ & $(0.57)$ & $(0.71)$ \\
\hline Union x 2008 - 2018 & $0.043 * *$ & $0.061 * * *$ & $0.067 * * *$ & $0.037 *$ & $0.046^{* *}$ & $0.052 * * *$ \\
\hline & $(2.00)$ & $(2.93)$ & $(3.14)$ & $(1.93)$ & $(2.41)$ & $(2.64)$ \\
\hline Male & & $0.017 * *$ & $0.022 * * *$ & & & \\
\hline & & $(1.99)$ & $(2.59)$ & & & \\
\hline Age in years & & $1.45 \times 10^{-4}$ & 0.003 & & & \\
\hline & & $(0.04)$ & $(0.76)$ & & & \\
\hline Age squared & & 0.002 & -0.002 & & & \\
\hline & & $(0.43)$ & $(0.28)$ & & & \\
\hline Black & & $-0.063 * * *$ & $-0.062 * * *$ & & & \\
\hline & & $(6.82)$ & $(6.43)$ & & & \\
\hline Hispanic & & $0.021 * *$ & $0.020^{*}$ & & & \\
\hline & & $(2.05)$ & $(1.88)$ & & & \\
\hline High school education & & $-0.032 * * *$ & $-0.032 * * *$ & & -0.005 & -0.003 \\
\hline & & $(3.35)$ & $(3.26)$ & & $(0.41)$ & $(0.27)$ \\
\hline College education & & $-0.040 * * *$ & $-0.048 * * *$ & & 0.009 & 0.009 \\
\hline & & $(2.86)$ & $(3.39)$ & & $(0.56)$ & $(0.52)$ \\
\hline Married & & $0.051 * * *$ & $0.054 * * *$ & & 0.006 & 0.010 \\
\hline & & $(7.67)$ & $(7.92)$ & & $(0.97)$ & $(1.63)$ \\
\hline Number of children & & 0.001 & 0.001 & & $0.005^{*}$ & 0.004 \\
\hline & & $(0.43)$ & $(0.27)$ & & $(1.66)$ & $(1.33)$ \\
\hline Constant & $3.042 * * *$ & $3.249 * * *$ & $3.248 * * *$ & $3.064 * * *$ & $3.166 * * *$ & $3.191 * * *$ \\
\hline Observations & 161,078 & 161,078 & 147,957 & 161,078 & 161,078 & 147,957 \\
\hline Missing obs. included & Yes & Yes & No & Yes & Yes & No \\
\hline Years (27) & Yes & Yes & Yes & Yes & Yes & Yes \\
\hline Regions (4) & No & Yes & Yes & No & Yes & Yes \\
\hline Occupations (21) & No & Yes & Yes & No & Yes & Yes \\
\hline Industries (15) & No & Yes & Yes & No & Yes & Yes \\
\hline R-squared & 0.013 & 0.042 & 0.038 & 0.012 & 0.037 & 0.032 \\
\hline F-statistic & 41.74 & 42.42 & 36.14 & 34.15 & 31.92 & 28.63 \\
\hline
\end{tabular}

Notes: the 1994 wave is omitted due to interview errors in the collection of union coverage information. The omitted category of time-periods is $1979-1988$. T-statistics are in parentheses. *,** and *** reflect statistical significance at the $10 \%, 5 \%$ and $1 \%$ levels, respectively. Heteroskedasticity robust standard errors are clustered at the individual level. Private sector. 
Table 3: Job Satisfaction, NLS97: 1997 - 2017

OLS pooled cross-sections

\begin{tabular}{|c|c|c|c|c|c|c|}
\hline \multirow{3}{*}{ Union } & (1) & (2) & (3) & (4) & (5) & (6) \\
\hline & -0.054 & -0.005 & -0.002 & -0.001 & -0.011 & -0.005 \\
\hline & $(2.15)$ & $(0.22)$ & $(0.08)$ & $(0.04)$ & $(0.47)$ & $(0.20)$ \\
\hline \multirow[t]{2}{*}{2008 - 2017} & 0.365 & -0.081 & -0.100 & 0.408 & 0.228 & 0.218 \\
\hline & $(9.50)$ & $(0.80)$ & $(0.97)$ & $(10.13)$ & $(5.10)$ & $(4.74)$ \\
\hline \multirow[t]{2}{*}{ Union x 2008 - 2017} & 0.047 & 0.057 & 0.052 & 0.070 & 0.071 & 0.065 \\
\hline & $(1.33)$ & $(1.65)$ & (1.49) & $(2.20)$ & $(2.261)$ & (2.05) \\
\hline \multirow[t]{2}{*}{ Male } & & 0.013 & 0.012 & & & \\
\hline & & $(0.87)$ & $(0.77)$ & & & \\
\hline \multirow[t]{2}{*}{ Age in years } & & 0.012 & 0.005 & & & \\
\hline & & $(0.64)$ & $(0.26)$ & & & \\
\hline \multirow[t]{2}{*}{ Age squared } & & 0.001 & 0.016 & & & \\
\hline & & $(0.02)$ & $(0.46)$ & & & \\
\hline \multirow[t]{2}{*}{ Black } & & -0.273 & -0.272 & & & \\
\hline & & $(14.51)$ & (14.33) & & & \\
\hline \multirow[t]{2}{*}{ Hispanic } & & 0.006 & 0.003 & & & \\
\hline & & $(0.33)$ & $(0.17)$ & & & \\
\hline \multirow[t]{2}{*}{ High school education } & & 0.052 & 0.052 & & 0.033 & 0.034 \\
\hline & & $(3.18)$ & (3.13) & & (1.93) & (1.97) \\
\hline \multirow[t]{2}{*}{ College education } & & 0.051 & 0.049 & & -0.030 & -0.036 \\
\hline & & $(2.31)$ & $(2.19)$ & & $(1.33)$ & $(1.56)$ \\
\hline \multirow[t]{2}{*}{ Married } & & 0.096 & 0.095 & & 0.005 & 0.005 \\
\hline & & $(6.39)$ & $(6.20)$ & & $(0.35)$ & $(0.31)$ \\
\hline \multirow[t]{2}{*}{ Number of children } & & -0.005 & -0.005 & & 0.002 & 0.002 \\
\hline & & $(1.02)$ & $(0.92)$ & & $(0.40)$ & $(0.42)$ \\
\hline Constant & 3.726 & 3.940 & 3.995 & 3.672 & 3.884 & 3.898 \\
\hline Observations & 67,750 & 67,750 & 65,097 & 67,750 & 67,750 & 65,097 \\
\hline Missing obs. included & Yes & Yes & No & Yes & Yes & No \\
\hline Years (18) & Yes & Yes & Yes & Yes & Yes & Yes \\
\hline Regions (4) & No & Yes & Yes & No & Yes & Yes \\
\hline Occupations (21) & No & Yes & Yes & No & Yes & Yes \\
\hline Industries (15) & No & Yes & Yes & No & Yes & Yes \\
\hline R-squared & 0.004 & 0.044 & 0.044 & 0.004 & 0.025 & 0.025 \\
\hline F-statistic & 14.19 & 23.07 & 23.18 & 16.11 & 15.03 & 14.93 \\
\hline
\end{tabular}

Notes: T-statistics are in parentheses. Heteroskedastic robust standard errors are clustered at the individual level. Private sector. 
Table 4: OLS Quit Estimates: NLS79: 1979 - 2018 OLS pooled cross-sections

\begin{tabular}{|c|c|c|c|c|c|c|}
\hline & (1) & (2) & (3) & (4) & (5) & (6) \\
\hline \multirow[t]{2}{*}{ Union } & -0.029 & -0.020 & -0.023 & -0.021 & -0.014 & -0.016 \\
\hline & $(12.51)$ & $(8.62)$ & $(9.91)$ & $(7.62)$ & $(5.13)$ & $(5.98)$ \\
\hline \multirow[t]{2}{*}{$1989-1996$} & 0.042 & 0.125 & 0.109 & 0.035 & 0.067 & 0.061 \\
\hline & $(11.55)$ & (18.39) & $(15.22)$ & $(9.00)$ & (15.05) & $(12.70)$ \\
\hline \multirow{2}{*}{$1998-2006$} & 0.040 & 0.133 & 0.117 & 0.040 & 0.075 & 0.067 \\
\hline & (10.19) & (13.94) & (11.69) & $(9.50)$ & (15.10) & (12.58) \\
\hline \multirow[t]{2}{*}{$2008-2018$} & 0.068 & 0.137 & 0.124 & 0.077 & 0.110 & 0.104 \\
\hline & (13.09) & $(8.82)$ & (7.87) & (14.31) & $(18.76)$ & (16.94) \\
\hline \multirow[t]{2}{*}{ Union x 1989 - 1996} & 0.006 & $3.84 \times 10^{-5}$ & 0.001 & 0.006 & 0.002 & 0.002 \\
\hline & $(1.70)$ & $(0.011)$ & $(0.19)$ & (1.69) & $(0.465)$ & $(0.526)$ \\
\hline \multirow[t]{2}{*}{ Union x 1998 - 2006} & 0.008 & 0.001 & 0.004 & 0.007 & 0.002 & 0.004 \\
\hline & $(1.70)$ & $(0.27)$ & $(0.81)$ & (1.37) & $(0.380)$ & $(0.74)$ \\
\hline \multirow[t]{2}{*}{ Union x 2008 - 2018} & 0.021 & 0.011 & 0.013 & 0.020 & 0.014 & 0.016 \\
\hline & (4.09) & $(2.13)$ & $(2.55)$ & (3.43) & (2.39) & $(2.70)$ \\
\hline \multirow[t]{2}{*}{ Male } & & -0.020 & -0.022 & & & \\
\hline & & (11.79) & (12.33) & & & \\
\hline \multirow[t]{2}{*}{ Age in years } & & -0.009 & -0.007 & & & \\
\hline & & $(8.86)$ & $(7.20)$ & & & \\
\hline \multirow[t]{2}{*}{ Age squared } & & 0.010 & 0.009 & & & \\
\hline & & (7.13) & $(5.80)$ & & & \\
\hline \multirow[t]{2}{*}{ Black } & & 0.013 & 0.013 & & & \\
\hline & & (6.134) & $(6.27)$ & & & \\
\hline \multirow[t]{2}{*}{ Hispanic } & & $-2.35 \times 10^{-4}$ & -0.001 & & & \\
\hline & & $(0.11)$ & $(0.46)$ & & & \\
\hline \multirow[t]{2}{*}{ High school education } & & -0.017 & -0.018 & & 0.009 & 0.006 \\
\hline & & (7.11) & $(7.30)$ & & $(2.30)$ & $(1.54)$ \\
\hline \multirow{2}{*}{ College education } & & -0.028 & -0.028 & & -0.047 & -0.052 \\
\hline & & $(9.32)$ & $(9.34)$ & & $(8.03)$ & $(8.51)$ \\
\hline \multirow[t]{2}{*}{ Married } & & -0.018 & -0.018 & & -0.009 & -0.007 \\
\hline & & $(11.38)$ & $(10.76)$ & & $(4.65)$ & $(3.59)$ \\
\hline \multirow[t]{2}{*}{ Number of children } & & $6.15 \times 10^{-5}$ & $5.20 \times 10^{-5}$ & & -0.004 & -0.003 \\
\hline & & $(0.08)$ & $(0.06)$ & & $(3.90)$ & $(3.53)$ \\
\hline Constant & 0.021 & 0.117 & 0.105 & 0.024 & -0.015 & -0.008 \\
\hline Observations & 161,078 & 161,078 & 147,957 & 161,078 & 161,078 & 147,957 \\
\hline Missing obs. included & Yes & Yes & No & Yes & Yes & No \\
\hline Years (27) & Yes & Yes & Yes & Yes & Yes & Yes \\
\hline Regions (4) & No & Yes & Yes & No & Yes & Yes \\
\hline Occupations (21) & No & Yes & Yes & No & Yes & Yes \\
\hline Industries (15) & No & Yes & Yes & No & Yes & Yes \\
\hline R-squared & 0.011 & 0.028 & 0.029 & 0.01 & 0.018 & 0.018 \\
\hline F-statistic & 64.86 & 41.93 & 44.25 & 48.79 & 27.04 & 29.2 \\
\hline
\end{tabular}

Notes: Quits are voluntary separations but exclude separations for family reasons or pregnancy. The 1994 wave is omitted due to interview errors in the collection of union coverage information. T-statistics are in parentheses. Heteroskedastic robust standard errors are clustered at the individual level.

Private sector. 
Table 5: OLS Quit Estimates: NLS97: 1997 - 2017

OLS pooled cross-sections

(1)

(2)

(3)

OLS fixed effects

\begin{tabular}{|c|c|c|c|c|c|c|}
\hline \multirow[t]{2}{*}{ Union } & -0.010 & -0.006 & -0.006 & 0.003 & 0.009 & 0.010 \\
\hline & $(1.73)$ & (1.07) & $(1.10)$ & $(0.40)$ & $(1.42)$ & $(1.50)$ \\
\hline \multirow[t]{2}{*}{$2008-2017$} & -0.159 & -0.006 & -0.006 & -0.049 & -0.115 & -0.110 \\
\hline & (11.962) & $(0.31)$ & $(0.31)$ & $(21.67)$ & $(7.80)$ & $(7.28)$ \\
\hline \multirow[t]{2}{*}{ Union x 2008 - 2017} & -0.008 & -0.012 & -0.013 & -0.003 & -0.011 & -0.012 \\
\hline & (1.08) & $(1.65)$ & $(1.75)$ & $(0.44)$ & $(1.43)$ & $(1.55)$ \\
\hline \multirow[t]{2}{*}{ Male } & & -0.001 & $-2.85 \times 10^{-4}$ & & & \\
\hline & & $(0.28)$ & $(0.11)$ & & & \\
\hline \multirow[t]{2}{*}{ Age in years } & & -0.021 & -0.021 & & & \\
\hline & & $(5.38)$ & $(5.26)$ & & & \\
\hline \multirow[t]{2}{*}{ Age squared } & & 0.031 & 0.031 & & & \\
\hline & & $(4.23)$ & $(4.14)$ & & & \\
\hline \multirow[t]{2}{*}{ Black } & & 0.021 & 0.020 & & & \\
\hline & & $(6.52)$ & $(6.36)$ & & & \\
\hline \multirow[t]{2}{*}{ Hispanic } & & -0.004 & -0.005 & & & \\
\hline & & $(1.43)$ & $(1.50)$ & & & \\
\hline \multirow[t]{2}{*}{ High school education } & & -0.022 & -0.023 & & 0.007 & 0.007 \\
\hline & & $(6.74)$ & $(6.68)$ & & $(1.56)$ & $(1.50)$ \\
\hline \multirow{2}{*}{ College education } & & -0.028 & -0.029 & & -0.032 & -0.033 \\
\hline & & (7.13) & $(7.12)$ & & $(5.67)$ & $(5.69)$ \\
\hline \multirow[t]{2}{*}{ Married } & & -0.019 & -0.019 & & -0.003 & -0.003 \\
\hline & & $(7.61)$ & (7.61) & & (1.06) & $(0.83)$ \\
\hline \multirow[t]{2}{*}{ Number of children } & & -0.002 & -0.001 & & -0.001 & -0.001 \\
\hline & & (1.61) & $(1.38)$ & & $(0.72)$ & $(0.61)$ \\
\hline Constant & 0.215 & 0.400 & 0.397 & 0.113 & 0.138 & 0.135 \\
\hline Observations & 85,155 & 85,155 & 82,271 & 85,155 & 85,155 & 82,271 \\
\hline Missing obs. included & Yes & Yes & No & Yes & Yes & No \\
\hline Years (18) & Yes & Yes & Yes & Yes & Yes & Yes \\
\hline Regions (4) & No & Yes & Yes & No & Yes & Yes \\
\hline Occupations (21) & No & Yes & Yes & No & Yes & Yes \\
\hline Industries (15) & No & Yes & Yes & No & Yes & Yes \\
\hline R-squared & 0.015 & 0.029 & 0.028 & 0.009 & 0.021 & 0.020 \\
\hline F-statistic & 59.12 & 34.19 & 33.73 & 173.95 & 19.60 & 19.13 \\
\hline
\end{tabular}

Notes: Quits are voluntary separations but exclude separations for family reasons or pregnancy. T-statistics are in parentheses. Heteroskedasticity robust standard errors are clustered at the individual level.

Private sector. 
Table 6. Unemployment, Underemployment and hourly wage differentials, 20002019

\begin{tabular}{ccc|cc} 
& \multicolumn{2}{c|}{ PTFER \% of employment } & Unemployment & Log hourly union \\
Non-union & rate \% & wage differential \\
2000 & 1.6 & 2.4 & 3.9 & 14.3 \\
2001 & 1.9 & 2.8 & 4.7 & 15.1 \\
2002 & 2.0 & 3.2 & 5.8 & 13.7 \\
2003 & 2.1 & 3.4 & 6.0 & 14.1 \\
2004 & 2.0 & 3.4 & 5.5 & 13.4 \\
2005 & 2.0 & 3.2 & 5.1 & 14.2 \\
2006 & 1.8 & 2.8 & 4.6 & 14.6 \\
2007 & 2.0 & 2.9 & 4.6 & 14.2 \\
2008 & 2.3 & 4.0 & 5.8 & 13.5 \\
2009 & 3.8 & 6.5 & 9.3 & 13.2 \\
2010 & 3.6 & 6.4 & 9.6 & 13.8 \\
2011 & 3.5 & 6.3 & 9.0 & 14.1 \\
2012 & 3.2 & 5.8 & 8.1 & 14.0 \\
2013 & 3.3 & 5.7 & 6.4 & 14.1 \\
2014 & 2.8 & 5.1 & 5.3 & 14.2 \\
2015 & 2.6 & 4.4 & 4.9 & 12.7 \\
2016 & 2.0 & 4.0 & 4.4 & 13.1 \\
2017 & 2.0 & 3.5 & 3.9 & 14.0 \\
2018 & 2.0 & 3.1 & 3.7 & 12.5 \\
2019 & 1.9 & 2.8 & & 12.1
\end{tabular}

Source: MORG files of the CPS and BLS (own calculations). 
Table 7. Well-being weighted means

$\begin{array}{lcc} & \text { Job satisfaction } & \text { Cantril } \\ \text { FT employee union } & .891 & 7.13 \\ \text { FT employee non-union } & .877 & 7.06 \\ \text { FT self-employed union } & .918 & 7.10 \\ \text { FT self-employed non-union } & .920 & 7.06 \\ \text { PT wants PT union } & .945 & 7.45 \\ \text { PT wants PT non-union } & .944 & 7.44 \\ \text { PT wants FT union } & .803 & 6.60 \\ \text { PT wants FT non-union } & .772 & 6.47 \\ \text { Unemployed } & \mathrm{n} / \mathrm{a} & 6.11 \\ \text { OLF } & \mathrm{n} / \mathrm{a} & 6.94 \\ \mathrm{~N} & 704,936 & 924,551\end{array}$

Source: Gallup US Daily Tracker, 2009-2013 for job satisfaction and 2009-2016 for the Cantril Scale which is based on the following question: "Please imagine a ladder, with steps numbered from 0 at the bottom to 10 at the top. The top represents the best possible life for you and the bottom of the ladder represents the worst possible life for you. On which step of the ladder would you say you personally feel you stand at this time?" 


\section{Table 8. Well-being and Underemployment, 2009-2016, workers only}

a) All workers, union main effect

$\begin{array}{lcc} & \text { Job satisfaction } & \text { Cantril life satisfaction } \\ \text { FT Self-employed } & .1820(20.82) & -.0012(0.18) \\ \text { PT doesn't want FT } & .3469(39.48) & .2046(34.90) \\ \text { PT wants FT } & -.3958(56.23) & -.5737(87.05) \\ \text { Union } & .0383(5.59) & .0631(11.23) \\ \text { Age } & -.0310(30.87) & -.0592(79.76) \\ \text { Age } * 100 & .0040(36.25) & .0631(81.24) \\ \text { Male } & -.0174(3.88) & -.2202(60.10) \\ \text { Constant } & 1.6182 & 8.1667 \\ \text { Adjusted/Pseudo R }{ }^{2} & .0425 & .0637 \\ \text { N } & & \\ \text { Weighted Mean } & 617,308 & 7.019\end{array}$

b) All workers, with union interaction

FT Self-employed

PT doesn't want FT

PT wants FT

Union

Union*PT wants FT

Age

$\operatorname{Age}^{2 * 100}$

Male

Constant

Adjusted/Pseudo $\mathrm{R}^{2}$

$\mathrm{N}$
Job satisfaction

$1814(20.74)$

$.3647(39.43)$

$-.4015(56.23)$

$.0326(4.59)$

$.0731(2.90)$

$-.0310(30.88)$

$.0040(36.26)$

$-.0175(3.88)$

1.6197

.0425

617,308
Cantril life satisfaction

$-.0017(0.26)$

$.2042(34.83)$

$-.5803(84.76)$

$.0584(10.10)$

.0857 (3.57)

$-.0592(79.77)$

$.0631(81.24)$

$-.2202(60.12)$

Notes: All equations include year, state, income; education and marital status dummies and \#children. Column 1 probit, column 2 OLS. Job satisfaction available only for 2009-2013. T-statistics in parentheses

Source: US Gallup Daily Tracker Poll. 

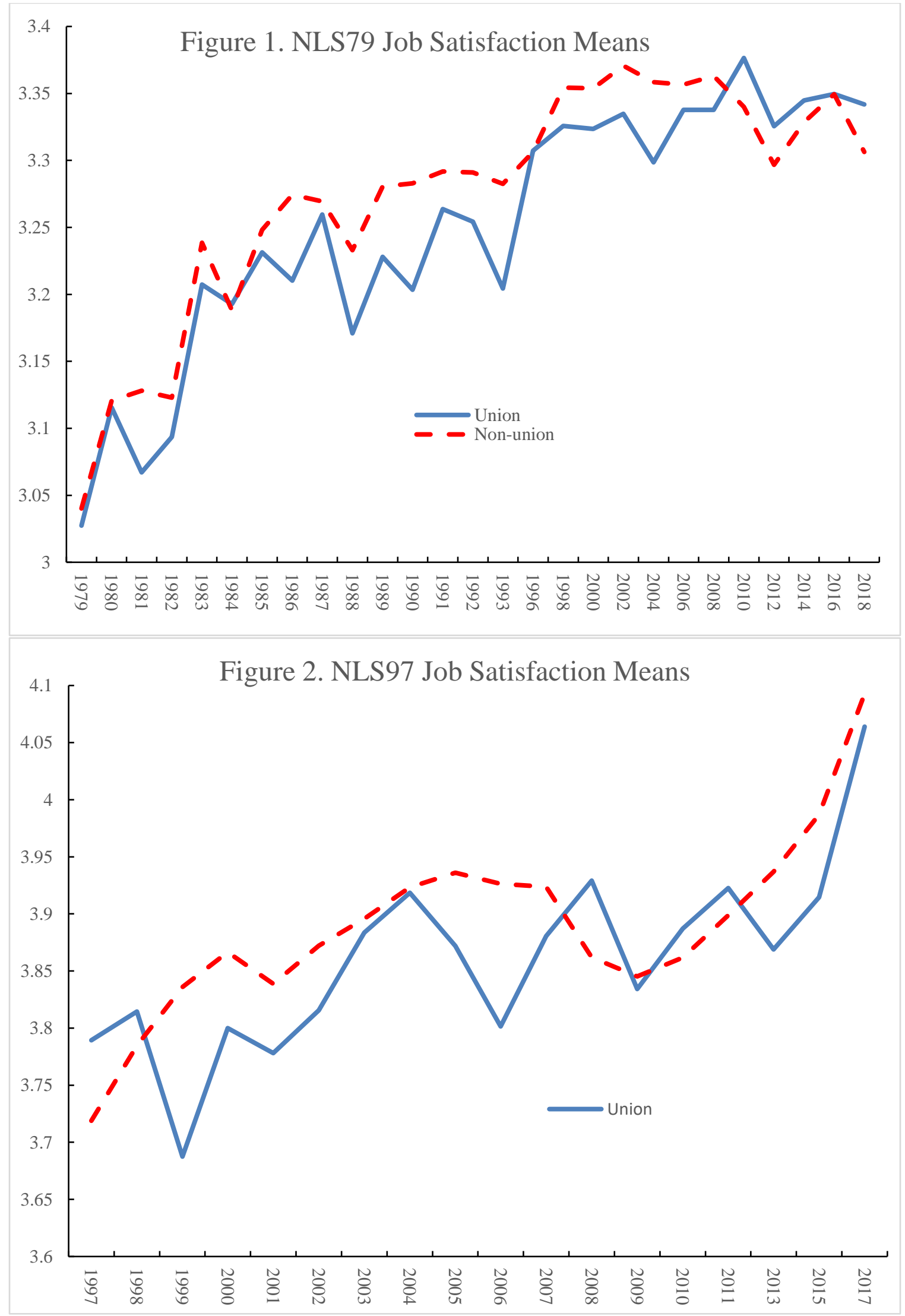


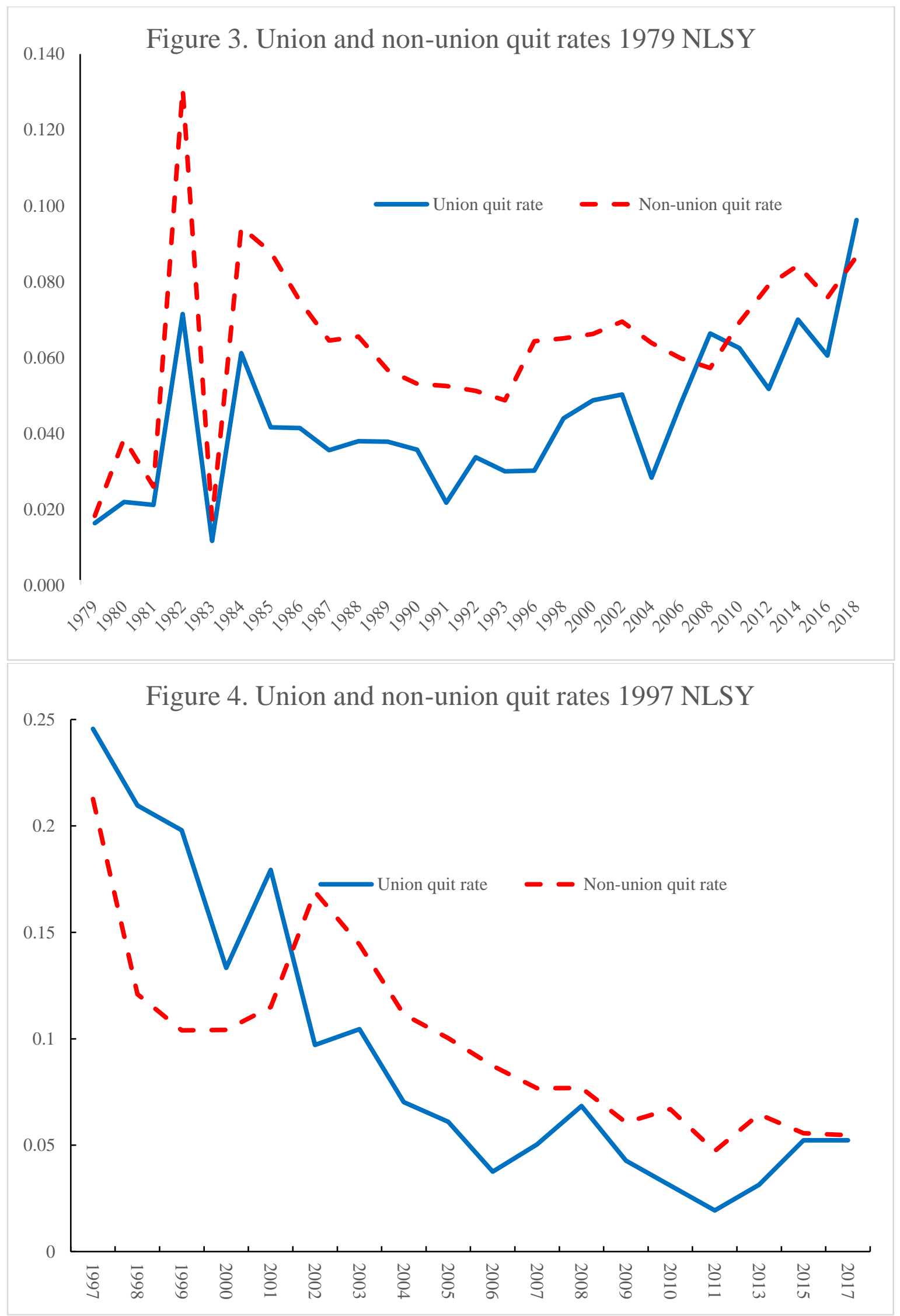




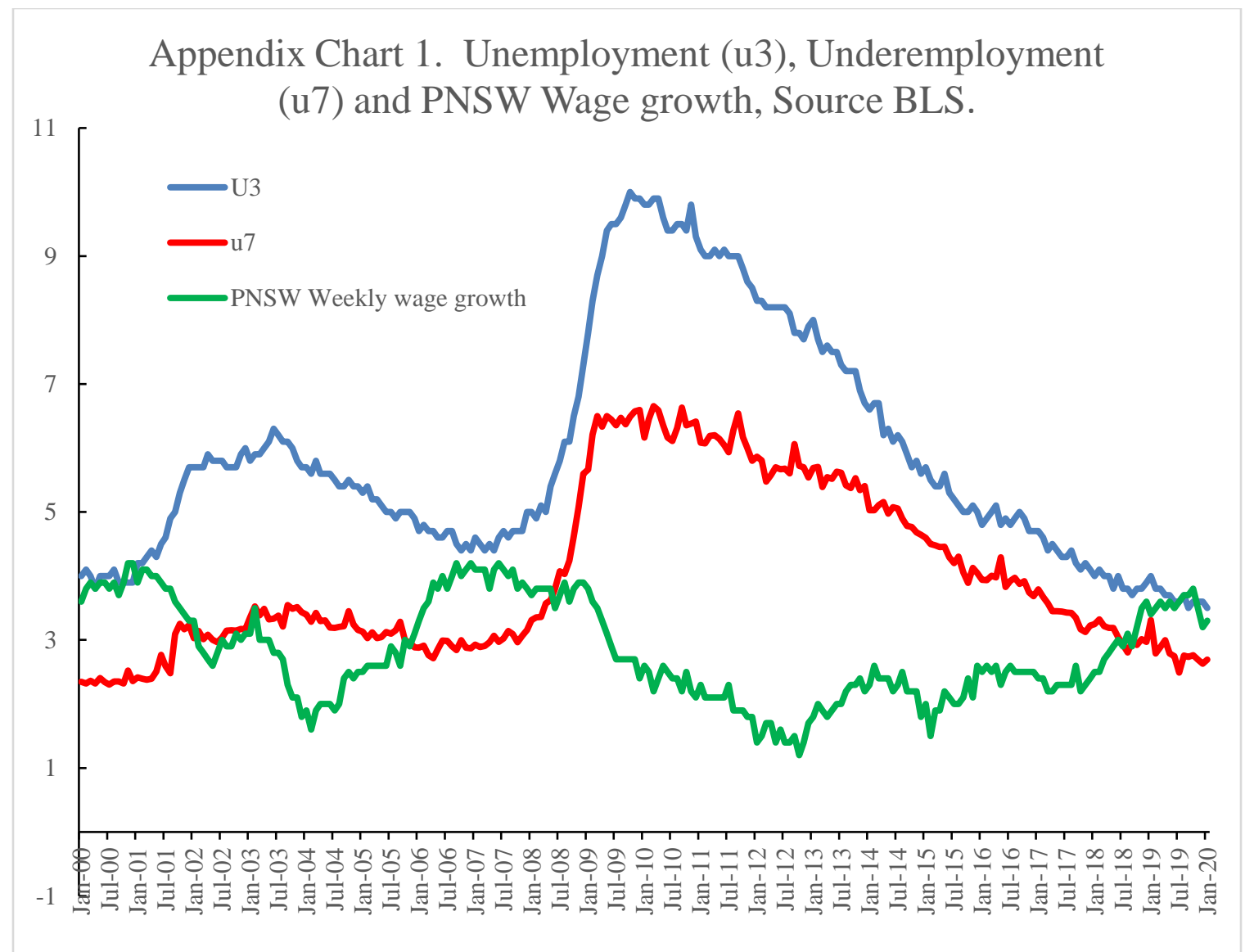


Appendix Table 1: Job Satisfaction, NLS79 \& NLS97, pre- and post-Great Recession

\begin{tabular}{|c|c|c|c|c|c|c|}
\hline & \multicolumn{3}{|c|}{ NLS79 Cohort OLS } & \multicolumn{3}{|c|}{ NLS97 Cohort OLS } \\
\hline & Pre-GR & Post-GR & $\begin{array}{l}\text { Whole } \\
\text { sample }\end{array}$ & Pre-GR & Post-GR & $\begin{array}{l}\text { Whole } \\
\text { sample }\end{array}$ \\
\hline \multirow[t]{2}{*}{ Union } & -0.008 & $0.046 * *$ & -0.007 & 0.005 & 0.042 & -0.005 \\
\hline & $(-0.922)$ & $(2.396)$ & $(-0.841)$ & $(0.214)$ & $(1.411)$ & $(-0.221)$ \\
\hline \multirow[t]{2}{*}{ Post-GR } & & & 0.063 & & & -0.081 \\
\hline & & & $(0.866)$ & & & $(-0.798)$ \\
\hline \multirow[t]{2}{*}{ Union $\mathrm{x}$ Post-GR } & & & $0.058 * * *$ & & & $0.057^{*}$ \\
\hline & & & $(3.110)$ & & & $(1.645)$ \\
\hline \multirow[t]{2}{*}{ Constant } & $3.327 * * *$ & $2.829 * * *$ & $3.249 * * *$ & $4.533 * * *$ & $3.170 * * *$ & $3.940 * * *$ \\
\hline & $(50.194)$ & $(3.866)$ & $(56.297)$ & $(10.361)$ & $(5.168)$ & $(17.758)$ \\
\hline Observations & 137,469 & 23,069 & 161,078 & 38,816 & 28,934 & 67,750 \\
\hline R-squared & 0.045 & 0.030 & 0.042 & 0.047 & 0.045 & 0.044 \\
\hline F-statistic & 47.80 & 7.23 & 43.51 & 19.69 & 14.11 & 23.07 \\
\hline
\end{tabular}


Appendix Table 2: Job Satisfaction, NLS79 \& NLS97, including a control for wages

\begin{tabular}{|c|c|c|c|c|c|c|c|c|}
\hline & \multicolumn{2}{|c|}{$\begin{array}{l}\text { NLS79 OLS pooled } \\
\text { cross-sections }\end{array}$} & \multicolumn{2}{|c|}{$\begin{array}{l}\text { NLS79 OLS Fixed } \\
\text { Effects }\end{array}$} & \multicolumn{2}{|c|}{$\begin{array}{l}\text { NLS97 OLS pooled } \\
\text { cross-sections }\end{array}$} & \multicolumn{2}{|c|}{$\begin{array}{c}\text { NLS97 OLS Fixed } \\
\text { Effects }\end{array}$} \\
\hline & (1) & (2) & (3) & (4) & (5) & (6) & (7) & (8) \\
\hline \multirow[t]{2}{*}{ Log hourly wage } & & $0.102 * * *$ & & $0.100 * * *$ & & $0.152 * * *$ & & $0.111 * * *$ \\
\hline & & (18.584) & & (19.792) & & (12.795) & & (10.049) \\
\hline \multirow[t]{2}{*}{ Union } & -0.017 & $-0.039 * * *$ & 0.014 & -0.003 & -0.006 & -0.024 & -0.013 & -0.022 \\
\hline & $(-1.638)$ & $(-3.737)$ & $(1.422)$ & $(-0.284)$ & $(-0.249)$ & $(-0.989)$ & $(-0.585)$ & $(-0.952)$ \\
\hline \multirow[t]{2}{*}{$1989-1996$} & $0.096 * * *$ & 0.030 & $0.138 * * *$ & 0.029 & & & & \\
\hline & $(3.022)$ & $(0.936)$ & $(8.104)$ & $(1.599)$ & & & & \\
\hline \multirow[t]{2}{*}{$1998-2006$} & $0.109 * *$ & 0.190 & $0.162 * * *$ & 0.019 & & & & \\
\hline & $(2.371)$ & $(0.411)$ & $(8.922)$ & $(0.950)$ & & & & \\
\hline \multirow[t]{2}{*}{$2008-2018$} & 0.046 & -0.079 & $0.101 * * *$ & $-0.073 * * *$ & & & & \\
\hline & $(0.627)$ & $(-1.070)$ & $(5.482)$ & $(-3.536)$ & & & & \\
\hline \multirow[t]{2}{*}{\begin{tabular}{|l} 
Union x 1989 - \\
1996
\end{tabular}} & 0.013 & 0.014 & 0.007 & 0.011 & & & & \\
\hline & $(0.843)$ & $(0.922)$ & $(0.509)$ & $(0.788)$ & & & & \\
\hline \multirow[t]{2}{*}{$\begin{array}{l}\text { Union x } 1998 \text { - } \\
2006\end{array}$} & 0.016 & 0.022 & 0.013 & 0.022 & & & & \\
\hline & $(0.838)$ & $(1.185)$ & $(0.739)$ & $(1.312)$ & & & & \\
\hline \multirow[t]{2}{*}{$\begin{array}{l}\text { Union x } 2008 \text { - } \\
2018\end{array}$} & $0.069 * * *$ & $0.073 * * *$ & $0.052 * * *$ & $0.057 * * *$ & & & & \\
\hline & (3.265) & (3.476) & $(2.672)$ & $(2.949)$ & & & & \\
\hline \multirow[t]{2}{*}{$2008-2017$} & & & & & -0.086 & -0.151 & $0.224 * * *$ & $0.102 * *$ \\
\hline & & & & & $(-0.838)$ & $(-1.478)$ & $(4.911)$ & $(2.138)$ \\
\hline \multirow[t]{2}{*}{$\begin{array}{l}\text { Union x } 2008 \text { - } \\
2017\end{array}$} & & & & & $0.063 *$ & 0.056 & $0.073 * *$ & $0.071 * *$ \\
\hline & & & & & $(1.810)$ & $(1.607)$ & $(2.289)$ & $(2.248)$ \\
\hline \multirow[t]{2}{*}{ Constant } & 3.236 *** & $2.677 * * *$ & $3.177 * * *$ & $2.585 * * *$ & $3.897 * * *$ & $2.917 * * *$ & $3.865 * * *$ & $3.124 * * *$ \\
\hline & $(54.133)$ & $(40.442)$ & $(114.325)$ & \begin{tabular}{|l}
$(63.900)$ \\
\end{tabular} & $(17.381)$ & (12.424) & (46.499) & $(28.632)$ \\
\hline Observations & 148,915 & 148,915 & 148,915 & 148,915 & 65,838 & 65,838 & 65,838 & 65,838 \\
\hline R-squared & 0.038 & 0.043 & 0.032 & 0.037 & 0.044 & 0.048 & 0.025 & 0.030 \\
\hline F-statistic & 35.09 & 38.07 & 28.22 & 32.84 & 22.29 & 24.53 & 14.22 & 15.73 \\
\hline \multicolumn{9}{|c|}{$\begin{array}{l}\text { Notes: All estimates include occupations, industries, regions, years, and demographic controls from Tables } \\
2 \text { and 3. T-statistics are in parentheses. *,** and *** reflect statistical significance at the } 10 \%, 5 \% \text { and } \\
1 \% \text { levels, respectively. Heteroskedasticity robust standard errors are clustered at the individual level. }\end{array}$} \\
\hline
\end{tabular}


Table 3: Job Satisfaction, NLS97: 1997 - 2017

OLS pooled cross-sections

\begin{tabular}{|c|c|c|c|c|c|c|}
\hline \multirow{3}{*}{ Union } & (1) & (2) & (3) & (4) & (5) & (6) \\
\hline & -0.054 & -0.005 & -0.002 & -0.001 & -0.011 & -0.005 \\
\hline & $(2.15)$ & $(0.22)$ & $(0.08)$ & $(0.04)$ & $(0.47)$ & $(0.20)$ \\
\hline \multirow[t]{2}{*}{$2008-2017$} & 0.365 & -0.081 & -0.100 & 0.408 & 0.228 & 0.218 \\
\hline & $(9.50)$ & $(0.80)$ & $(0.97)$ & $(10.13)$ & $(5.10)$ & $(4.74)$ \\
\hline \multirow[t]{2}{*}{ Union x 2008 - 2017} & 0.047 & 0.057 & 0.052 & 0.070 & 0.071 & 0.065 \\
\hline & $(1.33)$ & $(1.65)$ & $(1.49)$ & $(2.20)$ & $(2.261)$ & $(2.05)$ \\
\hline \multirow[t]{2}{*}{ Male } & & 0.013 & 0.012 & & & \\
\hline & & $(0.87)$ & $(0.77)$ & & & \\
\hline \multirow[t]{2}{*}{ Age in years } & & 0.012 & 0.005 & & & \\
\hline & & $(0.64)$ & $(0.26)$ & & & \\
\hline \multirow[t]{2}{*}{ Age squared } & & 0.001 & 0.016 & & & \\
\hline & & $(0.02)$ & $(0.46)$ & & & \\
\hline \multirow[t]{2}{*}{ Black } & & -0.273 & -0.272 & & & \\
\hline & & $(14.51)$ & (14.33) & & & \\
\hline \multirow[t]{2}{*}{ Hispanic } & & 0.006 & 0.003 & & & \\
\hline & & $(0.33)$ & $(0.17)$ & & & \\
\hline \multirow[t]{2}{*}{ High school education } & & 0.052 & 0.052 & & 0.033 & 0.034 \\
\hline & & $(3.18)$ & $(3.13)$ & & $(1.93)$ & $(1.97)$ \\
\hline \multirow[t]{2}{*}{ College education } & & 0.051 & 0.049 & & -0.030 & -0.036 \\
\hline & & $(2.31)$ & $(2.19)$ & & $(1.33)$ & $(1.56)$ \\
\hline \multirow[t]{2}{*}{ Married } & & 0.096 & 0.095 & & 0.005 & 0.005 \\
\hline & & $(6.39)$ & $(6.20)$ & & $(0.35)$ & $(0.31)$ \\
\hline \multirow[t]{2}{*}{ Number of children } & & -0.005 & -0.005 & & 0.002 & 0.002 \\
\hline & & $(1.02)$ & $(0.92)$ & & $(0.40)$ & $(0.42)$ \\
\hline Constant & 3.726 & 3.940 & 3.995 & 3.672 & 3.884 & 3.898 \\
\hline Observations & 67,750 & 67,750 & 65,097 & 67,750 & 67,750 & 65,097 \\
\hline Missing obs. included & Yes & Yes & No & Yes & Yes & No \\
\hline Years (18) & Yes & Yes & Yes & Yes & Yes & Yes \\
\hline Regions (4) & No & Yes & Yes & No & Yes & Yes \\
\hline Occupations (21) & No & Yes & Yes & No & Yes & Yes \\
\hline Industries (15) & No & Yes & Yes & No & Yes & Yes \\
\hline R-squared & 0.004 & 0.044 & 0.044 & 0.004 & 0.025 & 0.025 \\
\hline F-statistic & 14.19 & 23.07 & 23.18 & 16.11 & 15.03 & 14.93 \\
\hline
\end{tabular}

Notes: T-statistics are in parentheses. Heteroskedastic robust standard errors are clustered at the individual level. Private sector. 
Table 4: OLS Quit Estimates: NLS79: 1979 - 2018 OLS pooled cross-sections

\begin{tabular}{|c|c|c|c|c|c|c|}
\hline & (1) & (2) & (3) & (4) & (5) & (6) \\
\hline \multirow[t]{2}{*}{ Union } & -0.029 & -0.020 & -0.023 & -0.021 & -0.014 & -0.016 \\
\hline & $(12.51)$ & $(8.62)$ & $(9.91)$ & $(7.62)$ & $(5.13)$ & $(5.98)$ \\
\hline \multirow[t]{2}{*}{$1989-1996$} & 0.042 & 0.125 & 0.109 & 0.035 & 0.067 & 0.061 \\
\hline & $(11.55)$ & (18.39) & $(15.22)$ & $(9.00)$ & (15.05) & $(12.70)$ \\
\hline \multirow{2}{*}{$1998-2006$} & 0.040 & 0.133 & 0.117 & 0.040 & 0.075 & 0.067 \\
\hline & (10.19) & (13.94) & (11.69) & $(9.50)$ & (15.10) & (12.58) \\
\hline \multirow[t]{2}{*}{$2008-2018$} & 0.068 & 0.137 & 0.124 & 0.077 & 0.110 & 0.104 \\
\hline & (13.09) & $(8.82)$ & (7.87) & (14.31) & $(18.76)$ & (16.94) \\
\hline \multirow[t]{2}{*}{ Union x 1989 - 1996} & 0.006 & $3.84 \times 10^{-5}$ & 0.001 & 0.006 & 0.002 & 0.002 \\
\hline & $(1.70)$ & $(0.011)$ & $(0.19)$ & (1.69) & $(0.465)$ & $(0.526)$ \\
\hline \multirow[t]{2}{*}{ Union x 1998 - 2006} & 0.008 & 0.001 & 0.004 & 0.007 & 0.002 & 0.004 \\
\hline & $(1.70)$ & $(0.27)$ & $(0.81)$ & (1.37) & $(0.380)$ & $(0.74)$ \\
\hline \multirow[t]{2}{*}{ Union x 2008 - 2018} & 0.021 & 0.011 & 0.013 & 0.020 & 0.014 & 0.016 \\
\hline & (4.09) & $(2.13)$ & $(2.55)$ & (3.43) & (2.39) & $(2.70)$ \\
\hline \multirow[t]{2}{*}{ Male } & & -0.020 & -0.022 & & & \\
\hline & & (11.79) & (12.33) & & & \\
\hline \multirow[t]{2}{*}{ Age in years } & & -0.009 & -0.007 & & & \\
\hline & & $(8.86)$ & $(7.20)$ & & & \\
\hline \multirow[t]{2}{*}{ Age squared } & & 0.010 & 0.009 & & & \\
\hline & & (7.13) & $(5.80)$ & & & \\
\hline \multirow[t]{2}{*}{ Black } & & 0.013 & 0.013 & & & \\
\hline & & (6.134) & $(6.27)$ & & & \\
\hline \multirow[t]{2}{*}{ Hispanic } & & $-2.35 \times 10^{-4}$ & -0.001 & & & \\
\hline & & $(0.11)$ & $(0.46)$ & & & \\
\hline \multirow[t]{2}{*}{ High school education } & & -0.017 & -0.018 & & 0.009 & 0.006 \\
\hline & & (7.11) & $(7.30)$ & & $(2.30)$ & $(1.54)$ \\
\hline \multirow{2}{*}{ College education } & & -0.028 & -0.028 & & -0.047 & -0.052 \\
\hline & & $(9.32)$ & $(9.34)$ & & $(8.03)$ & $(8.51)$ \\
\hline \multirow[t]{2}{*}{ Married } & & -0.018 & -0.018 & & -0.009 & -0.007 \\
\hline & & $(11.38)$ & $(10.76)$ & & $(4.65)$ & $(3.59)$ \\
\hline \multirow[t]{2}{*}{ Number of children } & & $6.15 \times 10^{-5}$ & $5.20 \times 10^{-5}$ & & -0.004 & -0.003 \\
\hline & & $(0.08)$ & $(0.06)$ & & $(3.90)$ & $(3.53)$ \\
\hline Constant & 0.021 & 0.117 & 0.105 & 0.024 & -0.015 & -0.008 \\
\hline Observations & 161,078 & 161,078 & 147,957 & 161,078 & 161,078 & 147,957 \\
\hline Missing obs. included & Yes & Yes & No & Yes & Yes & No \\
\hline Years (27) & Yes & Yes & Yes & Yes & Yes & Yes \\
\hline Regions (4) & No & Yes & Yes & No & Yes & Yes \\
\hline Occupations (21) & No & Yes & Yes & No & Yes & Yes \\
\hline Industries (15) & No & Yes & Yes & No & Yes & Yes \\
\hline R-squared & 0.011 & 0.028 & 0.029 & 0.01 & 0.018 & 0.018 \\
\hline F-statistic & 64.86 & 41.93 & 44.25 & 48.79 & 27.04 & 29.2 \\
\hline
\end{tabular}

Notes: Quits are voluntary separations but exclude separations for family reasons or pregnancy. The 1994 wave is omitted due to interview errors in the collection of union coverage information. T-statistics are in parentheses. Heteroskedastic robust standard errors are clustered at the individual level.

Private sector. 
Table 5: OLS Quit Estimates: NLS97: 1997 - 2017

OLS pooled cross-sections

(1)

(2)

(3)

OLS fixed effects

\begin{tabular}{|c|c|c|c|c|c|c|}
\hline \multirow[t]{2}{*}{ Union } & -0.010 & -0.006 & -0.006 & 0.003 & 0.009 & 0.010 \\
\hline & $(1.73)$ & (1.07) & $(1.10)$ & $(0.40)$ & $(1.42)$ & $(1.50)$ \\
\hline \multirow[t]{2}{*}{$2008-2017$} & -0.159 & -0.006 & -0.006 & -0.049 & -0.115 & -0.110 \\
\hline & (11.962) & $(0.31)$ & $(0.31)$ & $(21.67)$ & $(7.80)$ & $(7.28)$ \\
\hline \multirow[t]{2}{*}{ Union x 2008 - 2017} & -0.008 & -0.012 & -0.013 & -0.003 & -0.011 & -0.012 \\
\hline & (1.08) & $(1.65)$ & $(1.75)$ & $(0.44)$ & $(1.43)$ & $(1.55)$ \\
\hline \multirow[t]{2}{*}{ Male } & & -0.001 & $-2.85 \times 10^{-4}$ & & & \\
\hline & & $(0.28)$ & $(0.11)$ & & & \\
\hline \multirow[t]{2}{*}{ Age in years } & & -0.021 & -0.021 & & & \\
\hline & & $(5.38)$ & $(5.26)$ & & & \\
\hline \multirow[t]{2}{*}{ Age squared } & & 0.031 & 0.031 & & & \\
\hline & & $(4.23)$ & $(4.14)$ & & & \\
\hline \multirow[t]{2}{*}{ Black } & & 0.021 & 0.020 & & & \\
\hline & & $(6.52)$ & $(6.36)$ & & & \\
\hline \multirow[t]{2}{*}{ Hispanic } & & -0.004 & -0.005 & & & \\
\hline & & $(1.43)$ & $(1.50)$ & & & \\
\hline \multirow[t]{2}{*}{ High school education } & & -0.022 & -0.023 & & 0.007 & 0.007 \\
\hline & & $(6.74)$ & $(6.68)$ & & $(1.56)$ & $(1.50)$ \\
\hline \multirow{2}{*}{ College education } & & -0.028 & -0.029 & & -0.032 & -0.033 \\
\hline & & (7.13) & $(7.12)$ & & $(5.67)$ & $(5.69)$ \\
\hline \multirow[t]{2}{*}{ Married } & & -0.019 & -0.019 & & -0.003 & -0.003 \\
\hline & & $(7.61)$ & (7.61) & & (1.06) & $(0.83)$ \\
\hline \multirow[t]{2}{*}{ Number of children } & & -0.002 & -0.001 & & -0.001 & -0.001 \\
\hline & & (1.61) & $(1.38)$ & & $(0.72)$ & $(0.61)$ \\
\hline Constant & 0.215 & 0.400 & 0.397 & 0.113 & 0.138 & 0.135 \\
\hline Observations & 85,155 & 85,155 & 82,271 & 85,155 & 85,155 & 82,271 \\
\hline Missing obs. included & Yes & Yes & No & Yes & Yes & No \\
\hline Years (18) & Yes & Yes & Yes & Yes & Yes & Yes \\
\hline Regions (4) & No & Yes & Yes & No & Yes & Yes \\
\hline Occupations (21) & No & Yes & Yes & No & Yes & Yes \\
\hline Industries (15) & No & Yes & Yes & No & Yes & Yes \\
\hline R-squared & 0.015 & 0.029 & 0.028 & 0.009 & 0.021 & 0.020 \\
\hline F-statistic & 59.12 & 34.19 & 33.73 & 173.95 & 19.60 & 19.13 \\
\hline
\end{tabular}

Notes: Quits are voluntary separations but exclude separations for family reasons or pregnancy. T-statistics are in parentheses. Heteroskedasticity robust standard errors are clustered at the individual level.

Private sector. 
Table 6. Unemployment, Underemployment and hourly wage differentials, 20002019

\begin{tabular}{ccc|cc} 
& \multicolumn{2}{c|}{ PTFER \% of employment } & Unemployment & Log hourly union \\
Non-union & rate \% & wage differential \\
2000 & 1.6 & 2.4 & 3.9 & 14.3 \\
2001 & 1.9 & 2.8 & 4.7 & 15.1 \\
2002 & 2.0 & 3.2 & 5.8 & 13.7 \\
2003 & 2.1 & 3.4 & 6.0 & 14.1 \\
2004 & 2.0 & 3.4 & 5.5 & 13.4 \\
2005 & 2.0 & 3.2 & 5.1 & 14.2 \\
2006 & 1.8 & 2.8 & 4.6 & 14.6 \\
2007 & 2.0 & 2.9 & 4.6 & 14.2 \\
2008 & 2.3 & 4.0 & 5.8 & 13.5 \\
2009 & 3.8 & 6.5 & 9.3 & 13.2 \\
2010 & 3.6 & 6.4 & 9.6 & 13.8 \\
2011 & 3.5 & 6.3 & 9.0 & 14.1 \\
2012 & 3.2 & 5.8 & 8.1 & 14.0 \\
2013 & 3.3 & 5.7 & 6.4 & 14.1 \\
2014 & 2.8 & 5.1 & 5.3 & 14.2 \\
2015 & 2.6 & 4.4 & 4.9 & 12.7 \\
2016 & 2.0 & 4.0 & 4.4 & 13.1 \\
2017 & 2.0 & 3.5 & 3.9 & 14.0 \\
2018 & 2.0 & 3.1 & 3.7 & 12.5 \\
2019 & 1.9 & 2.8 & & 12.1
\end{tabular}

Source: MORG files of the CPS and BLS (own calculations). 
Table 7. Well-being weighted means

$\begin{array}{lcc} & \text { Job satisfaction } & \text { Cantril } \\ \text { FT employee union } & .891 & 7.13 \\ \text { FT employee non-union } & .877 & 7.06 \\ \text { FT self-employed union } & .918 & 7.10 \\ \text { FT self-employed non-union } & .920 & 7.06 \\ \text { PT wants PT union } & .945 & 7.45 \\ \text { PT wants PT non-union } & .944 & 7.44 \\ \text { PT wants FT union } & .803 & 6.60 \\ \text { PT wants FT non-union } & .772 & 6.47 \\ \text { Unemployed } & \text { n/a } & 6.11 \\ \text { OLF } & \text { n/a } & 6.94 \\ \text { N } & 704,936 & 924,551\end{array}$

Source: Gallup US Daily Tracker, 2009-2013 for job satisfaction and 2009-2016 for the Cantril Scale which is based on the following question: "Please imagine a ladder, with steps numbered from 0 at the bottom to 10 at the top. The top represents the best possible life for you and the bottom of the ladder represents the worst possible life for you. On which step of the ladder would you say you personally feel you stand at this time?" 


\section{Table 8. Well-being and Underemployment, 2009-2016, workers only}

a) All workers, union main effect

$\begin{array}{lcc} & \text { Job satisfaction } & \text { Cantril life satisfaction } \\ \text { FT Self-employed } & .1820(20.82) & -.0012(0.18) \\ \text { PT doesn't want FT } & .3469(39.48) & .2046(34.90) \\ \text { PT wants FT } & -.3958(56.23) & -.5737(87.05) \\ \text { Union } & .0383(5.59) & .0631(11.23) \\ \text { Age } & -.0310(30.87) & -.0592(79.76) \\ \text { Age } * 100 & .0040(36.25) & .0631(81.24) \\ \text { Male } & -.0174(3.88) & -.2202(60.10) \\ \text { Constant } & 1.6182 & 8.1667 \\ \text { Adjusted/Pseudo R }{ }^{2} & .0425 & .0637 \\ \text { N } & & \\ \text { Weighted Mean } & 617,308 & 7.019\end{array}$

b) All workers, with union interaction

FT Self-employed

PT doesn't want FT

PT wants FT

Union

Union*PT wants FT

Age

$\operatorname{Age}^{2 * 100}$

Male

Constant

Adjusted/Pseudo $\mathrm{R}^{2}$

$\mathrm{N}$
Job satisfaction

$1814(20.74)$

$.3647(39.43)$

$-.4015(56.23)$

$.0326(4.59)$

$.0731(2.90)$

$-.0310(30.88)$

$.0040(36.26)$

$-.0175(3.88)$

1.6197

.0425

617,308
Cantril life satisfaction

$-.0017(0.26)$

$.2042(34.83)$

$-.5803(84.76)$

$.0584(10.10)$

.0857 (3.57)

$-.0592(79.77)$

$.0631(81.24)$

$-.2202(60.12)$

Notes: All equations include year, state, income; education and marital status dummies and \#children. Column 1 probit, column 2 OLS. Job satisfaction available only for 2009-2013. T-statistics in parentheses

Source: US Gallup Daily Tracker Poll. 

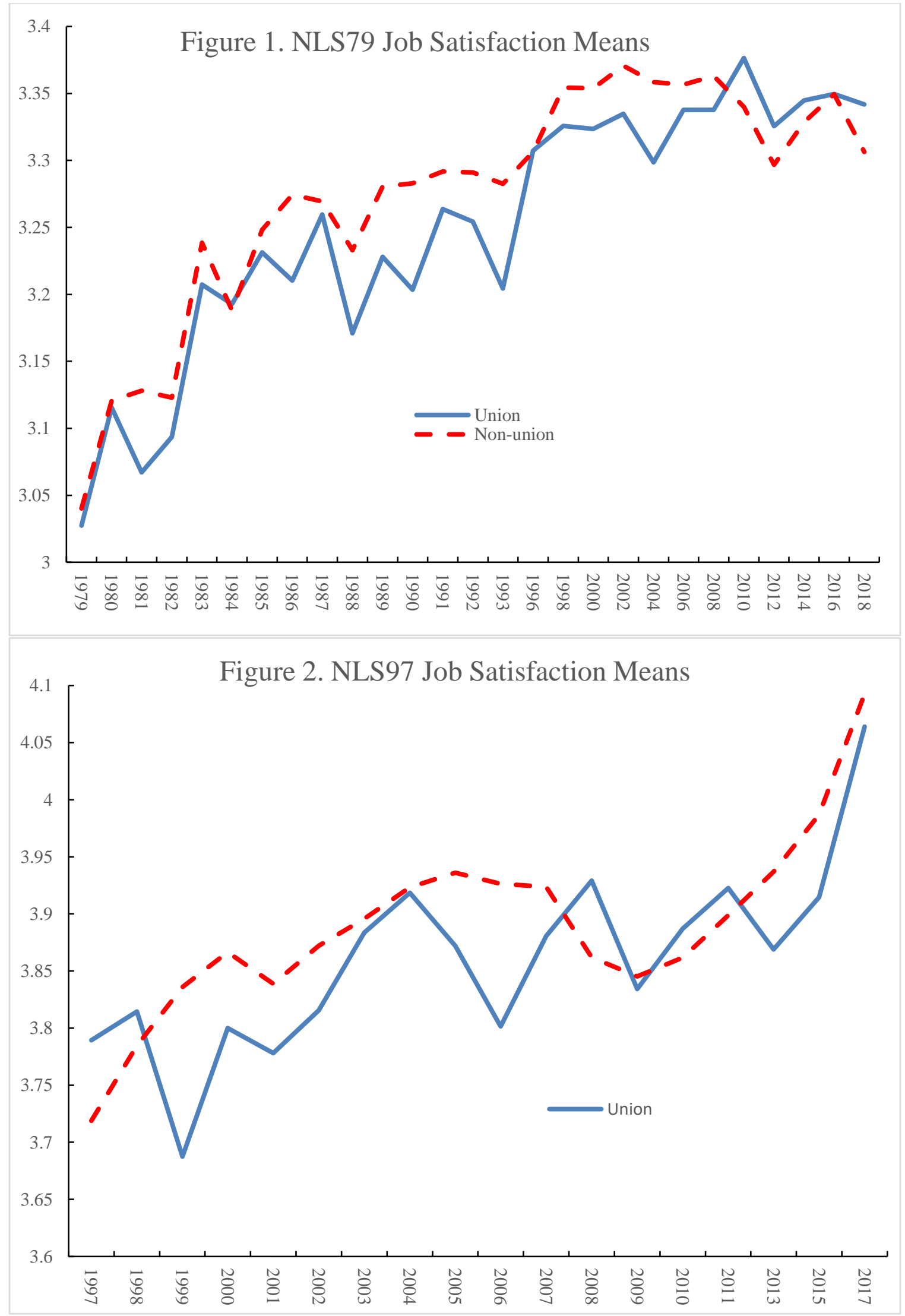


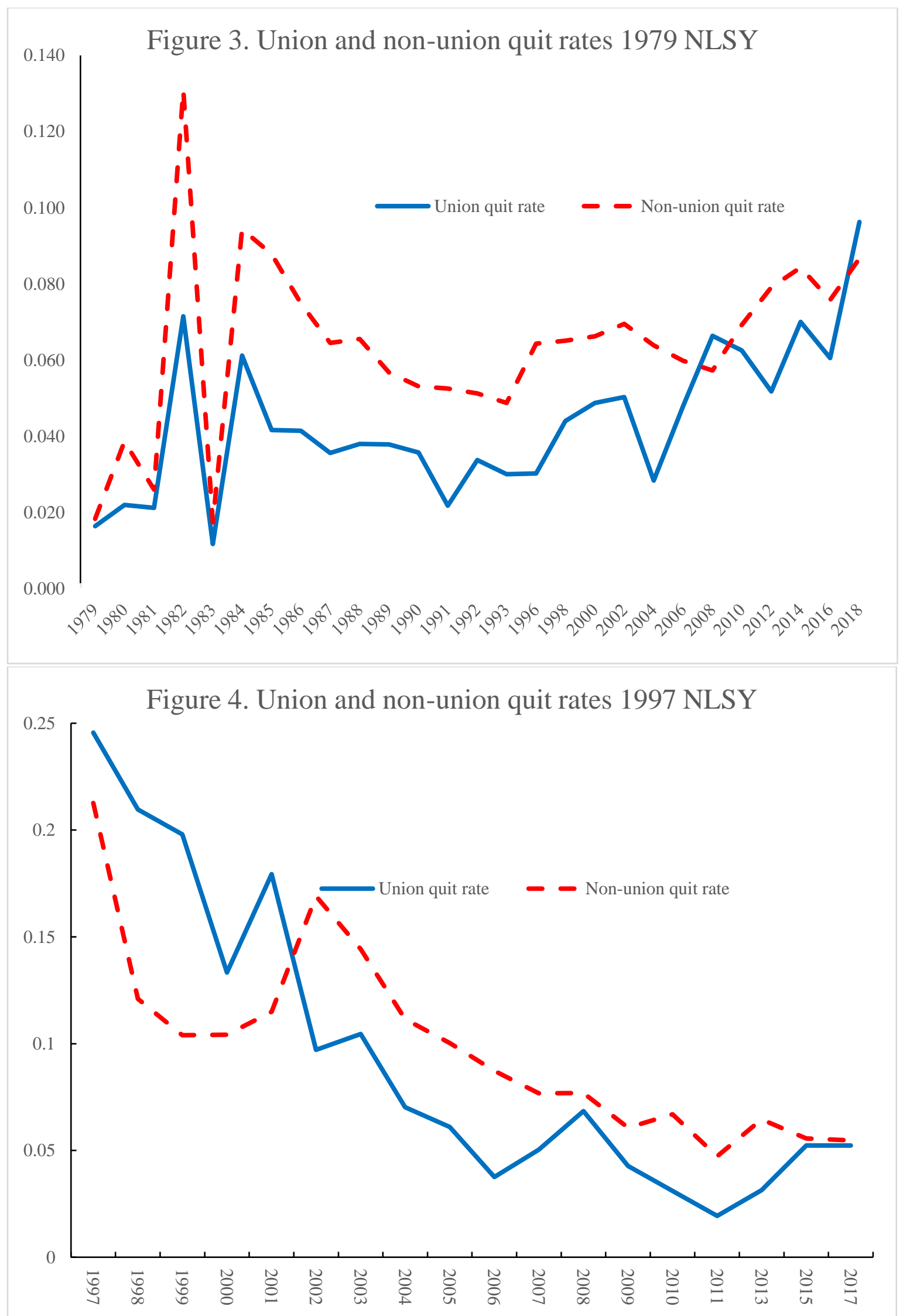




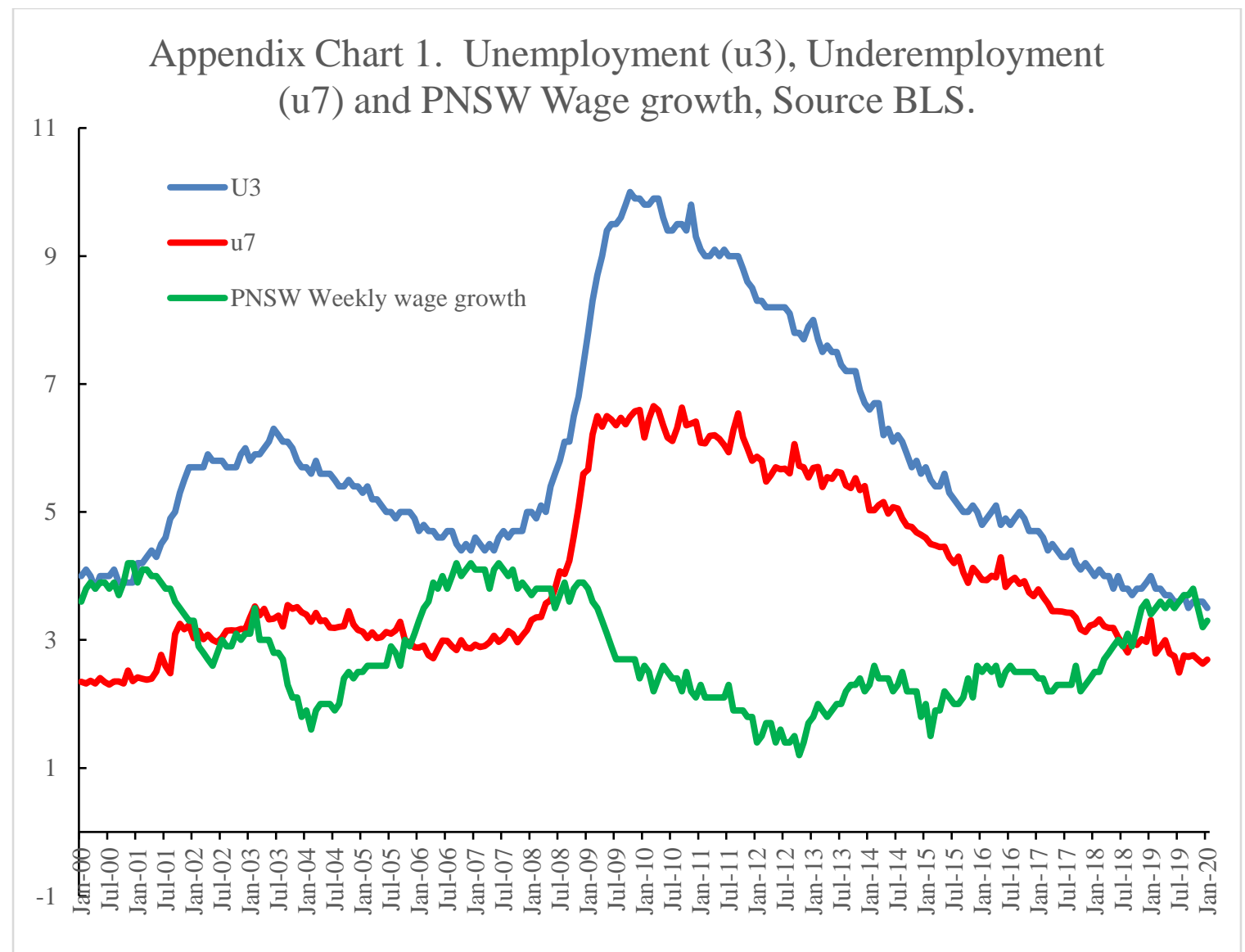


Appendix Table 1: Job Satisfaction, NLS79 \& NLS97, pre- and post-Great Recession

\begin{tabular}{|c|c|c|c|c|c|c|}
\hline & \multicolumn{3}{|c|}{ NLS79 Cohort OLS } & \multicolumn{3}{|c|}{ NLS97 Cohort OLS } \\
\hline & Pre-GR & Post-GR & $\begin{array}{l}\text { Whole } \\
\text { sample }\end{array}$ & Pre-GR & Post-GR & $\begin{array}{l}\text { Whole } \\
\text { sample }\end{array}$ \\
\hline \multirow[t]{2}{*}{ Union } & -0.008 & $0.046 * *$ & -0.007 & 0.005 & 0.042 & -0.005 \\
\hline & $(-0.922)$ & $(2.396)$ & $(-0.841)$ & $(0.214)$ & $(1.411)$ & $(-0.221)$ \\
\hline \multirow[t]{2}{*}{ Post-GR } & & & 0.063 & & & -0.081 \\
\hline & & & $(0.866)$ & & & $(-0.798)$ \\
\hline \multirow[t]{2}{*}{ Union x Post-GR } & & & $0.058 * * *$ & & & $0.057 *$ \\
\hline & & & $(3.110)$ & & & $(1.645)$ \\
\hline \multirow[t]{2}{*}{ Constant } & $3.327 * * *$ & $2.829 * * *$ & $3.249 * * *$ & $4.533 * * *$ & $3.170 * * *$ & $3.940 * * *$ \\
\hline & $(50.194)$ & $(3.866)$ & $(56.297)$ & $(10.361)$ & $(5.168)$ & $(17.758)$ \\
\hline Observations & 137,469 & 23,069 & 161,078 & 38,816 & 28,934 & 67,750 \\
\hline R-squared & 0.045 & 0.030 & 0.042 & 0.047 & 0.045 & 0.044 \\
\hline F-statistic & 47.80 & 7.23 & 43.51 & 19.69 & 14.11 & 23.07 \\
\hline
\end{tabular}


Appendix Table 2: Job Satisfaction, NLS79 \& NLS97, including a control for wages

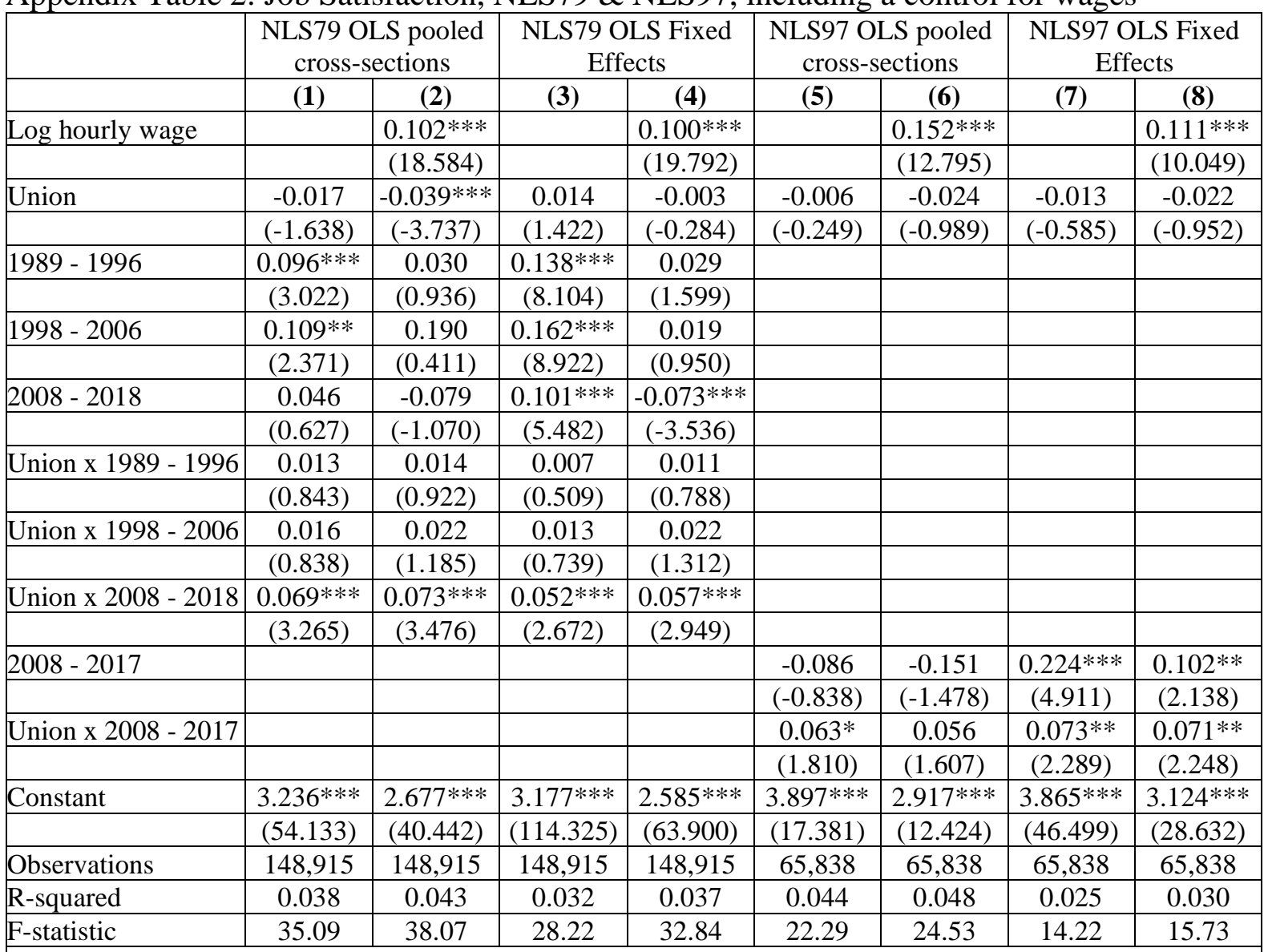

Notes: All estimates include occupations, industries, regions, years, and demographic controls from Tables 2 and 3. T-statistics are in parentheses. *, ** and *** reflect statistical significance at the $10 \%, 5 \%$ and $1 \%$ levels, respectively. Heteroskedasticity robust standard errors are clustered at the individual level. 